Mycologia, 96(4), 2004, pp. 891-910.

(C) 2004 by The Mycological Society of America, Lawrence, KS 66044-8897

\title{
Fungal symbionts (Harpellales) in Norwegian aquatic insect larvae
}

\author{
Merlin M. White ${ }^{1}$ \\ Robert W. Lichtwardt \\ Department of Ecology and Evolutionary Biology, \\ University of Kansas, Lawrence, Kansas 66045-7534
}

\begin{abstract}
Collections of aquatic insect larvae in Norway, over a 40 d period in May and Aug 2002, resulted in finding more than 25 species and one new genus of Harpellales (Trichomycetes). Nine new fungal symbionts are described and named: Ephemerellomyces aquilonius (a new monotypic genus), Glotzia stenospora and Legeriosimilis europaeus in mayfly nymphs (Ephemeroptera); Genistelloides amplispora and G. communis in stonefly nymphs (Plecoptera); and Smittium biforme, Sm. precipitiorum, Stachylina acutibasilaris and St. lentica in midge larvae (Diptera: Chironomidae). Two possibly new species of Smittium in Chironomidae larvae are described but not formally named. New hosts and biogeographical distributions are recorded for 14 previously described species, including the rare occurrence of Smittium simulii in mosquito larvae.
\end{abstract}

Key words: biogeography, Diptera, Ephemeroptera, gut fungi, Plecoptera, symbiosis, Thaumaleidae, Trichomycetes

\section{INTRODUCTION}

We encountered many new gut fungi in the course of seeking particular living specimens of Harpellales in Norway for preservation and subsequent extraction of their DNA to be used in a comparative molecular study of North American and European species. This paper provides descriptions of nine new species, including one new genus, as well as new host records and other data on geographic distributions of previously described Harpellales. Two possibly new species of Smittium, the largest genus of Harpellales, are described but not named. Several previously known species are illustrated in this paper to document their identification and/or to provide photomicrographs not currently available in the literature.

Norway had an excellent diversity of Harpellales in

Accepted for publication January 14, 2004.

${ }^{1}$ Corresponding author. E-mail: trichos@ku.edu various kinds of aquatic habitats, considering that collections and laboratory work were conducted within a total of only $40 \mathrm{~d}$ and over a restricted range of possible habitats. The months of May and Aug were selected to obtain some of the insects in their more mature larval stages. In particular, we sought two of the least vagile aquatic insect hosts of gut fungi, stonefly nymphs (Plecoptera) (Hynes 1975, 1988, Stewart and Stark 1988) and solitary midge larvae (Thaumaleidae), hosts of Orphella and Harpellomyces, respectively. We did not find solitary midges in their usual seeping cliff habitats in May, but we did encounter them in Aug, even though it was one of the driest summer seasons in several decades according to local accounts. Undoubtedly, many other Harpellales beyond the taxa we describe here are present in Norway, especially in unexplored regions of the country and in different hosts, habitats and time of year.

\section{MATERIALS AND METHODS}

Collecting sites where Harpellales were found are listed in TABLE I. Most insects were collected in flowing streams. Aquatic nets or strainers were used in streams, ponds and rock pools, or insects were picked up with forceps directly from substrate materials in these habitats and from seeping cliffs. Supplemental bulk collections were placed in sealed plastic bags for later sorting. Jars and bags with insects were kept on ice until returned to the laboratory, then placed in refrigerators until dissected.

Laboratory facilities in May were provided first by the University of Oslo's Botany Department and then at the Ekse Field Station (in the mountains west and north of Voss) administered by the University of Bergen. In Aug work was conducted at the University of Trondheim's Lake Snåsavatnet Field Station east of Steinkjer. Collection sites were selected from as wide an area as possible, usually within a half day's drive of the facilities.

Dissections of insects were done under stereo microscopes, and their gut fungi studied and identified in water mounts using a phase-contrast microscope. The fungi selectively were photomicrographed (using Kodak 200 ISO daylight print film) in living condition, then either placed in CTAB DNA extraction buffer (Gottlieb and Lichtwardt 2001) for subsequent sequencing in our own laboratory or prepared as semipermanent slides by infiltrating lactophenol-cotton blue under the cover slip and sealing with clear fingernail polish. Some specimens were selected for culture attempts, using methods described in Lichtwardt et al (2001a). Types of new species are deposited at the Farlow Herbarium (FH). 
TABLE I. Collection sites in Norway with Harpellales

\begin{tabular}{|c|c|c|c|}
\hline Site & Date & Site description, County, Municipality & Latitude/Longitude \\
\hline 2 & 3-V-2002 & $\begin{array}{l}\text { Stream near curve on Sørkendalsveien Rd. Oslo. } \\
\text { Water temperature } 5.5 \text { C. }\end{array}$ & $60^{\circ} 00.72^{\prime} \mathrm{N}, 10^{\circ} 36.74^{\prime} \mathrm{E}$ \\
\hline 3 & 3-V-2002 & $\begin{array}{l}\text { Heggelielva River near Skansebakken parking area. } \\
\text { Oslo. 8.5 C. }\end{array}$ & $60^{\circ} 01.19^{\prime} \mathrm{N}, 10^{\circ} 35.20^{\prime} \mathrm{E}$ \\
\hline 4 & 3-V-2002 & $\begin{array}{l}\text { Small stream next to house at old bridge immedi- } \\
\text { ately } \mathrm{N} \text { of newer bridge. Oslo. } 5 \mathrm{C} \text {. }\end{array}$ & $60^{\circ} 01.14^{\prime} \mathrm{N}, 10^{\circ} 33.88^{\prime} \mathrm{E}$ \\
\hline 5 & 5-V-2002 & $\begin{array}{l}\text { Small unnamed stream off Kampeveien Rd. Oslo. } \\
6.5 \text { C. }\end{array}$ & $59^{\circ} 59.19^{\prime} \mathrm{N}, 10^{\circ} 28.64^{\prime} \mathrm{E}$ \\
\hline 6 & $5-\mathrm{V}-2002$ & $\begin{array}{l}\text { Østernbekken River, crossing road on Rt. } 168 \text { to } \\
\text { Haga. Oslo. } 10 \text { C. }\end{array}$ & $59^{\circ} 56.52^{\prime} \mathrm{N}, 10^{\circ} 34.70^{\prime} \mathrm{E}$ \\
\hline 7 & $5-\mathrm{V}-2002$ & $\begin{array}{l}\text { Stream near curve on Sørkendalsveien Rd. Oslo. } 7 \\
\text { C. }\end{array}$ & $60^{\circ} 00.72^{\prime} \mathrm{N}, 10^{\circ} 36.74^{\prime} \mathrm{E}$ \\
\hline 8 & 8-V-2002 & $\begin{array}{l}\text { Heggelielva River near Skansebakken parking area. } \\
\text { Oslo. } 8.5 \mathrm{C} \text {. }\end{array}$ & $60^{\circ} 01.19^{\prime} \mathrm{N}, 10^{\circ} 35.20^{\prime} \mathrm{E}$ \\
\hline 10 & $8-\mathrm{V}-2002$ & $\begin{array}{l}\text { Small stream next to house at old bridge, immedi- } \\
\text { ately } \mathrm{N} \text { of newer bridge. Oslo. } 6.5 \mathrm{C} \text {. }\end{array}$ & $60^{\circ} 01.14^{\prime} \mathrm{N}, 10^{\circ} 33.88^{\prime} \mathrm{E}$ \\
\hline 11 & $9-\mathrm{V}-2002$ & Svenodalen River. Oppland, Jevnaker. 5 C. & $60^{\circ} 13.86^{\prime} \mathrm{N}, 10^{\circ} 25.81^{\prime} \mathrm{E}$ \\
\hline $11 \mathrm{~A}$ & 9-V-2002 & $\begin{array}{l}\text { Seepy cliff bordering Svenodalen River about } 1 \mathrm{~km} \\
\text { upstream from Site 11. Oppland, Jevnaker. }\end{array}$ & \\
\hline 15 & $9-\mathrm{V}-2002$ & $\begin{array}{l}\text { Small tributary of River Kverndøla. Akershus, Eids- } \\
\text { voll. }\end{array}$ & $60^{\circ} 15.82^{\prime} \mathrm{N}, 10^{\circ} 57.68^{\prime} \mathrm{E}$ \\
\hline 16 & $9-\mathrm{V}-2002$ & Dalbekken stream. Akershus, Eidsvoll. 6 C. & $60^{\circ} 29.99^{\prime} \mathrm{N}, 10^{\circ} 08.00^{\prime} \mathrm{E}$ \\
\hline 17 & $13-\mathrm{V}-2002$ & $\begin{array}{l}\text { Seepy cliff on Rt. 7, } 11.5 \text { km from Ørgenvika. Bus- } \\
\text { kerud, Flå. }\end{array}$ & $60^{\circ} 11.98^{\prime} \mathrm{N}, 09^{\circ} 37.59^{\prime} \mathrm{E}$ \\
\hline 18 & $13-\mathrm{V}-2002$ & $\begin{array}{l}\text { Seepy cliff on Rt. } 7 \text { at large parking area. Buske- } \\
\text { rud, Gol. } 9 \text { C. }\end{array}$ & $60^{\circ} 28.31^{\prime} \mathrm{N}, 09^{\circ} 56.68^{\prime} \mathrm{E}$ \\
\hline 19 & $14-\mathrm{V}-2002$ & $\begin{array}{l}\text { Stream at bottom of Haga foss, a tributary of the } \\
\text { Ekso River. Hordaland, Modalen. } 2 \text { C. }\end{array}$ & $60^{\circ} 50.11^{\prime} \mathrm{N}, 06^{\circ} 19.48^{\prime} \mathrm{E}$ \\
\hline 20 & $15-\mathrm{V}-2002$ & $\begin{array}{l}\text { Very small stream on E edge of Ekse field station } \\
\text { building. Hordaland, Modalen. }\end{array}$ & $60^{\circ} 49.77^{\prime} \mathrm{N}, 06^{\circ} 14.37^{\prime} \mathrm{E}$ \\
\hline 21 & $15-\mathrm{V}-2002$ & $\begin{array}{l}\text { Stream at bottom of Haga foss, a tributary of the } \\
\text { Ekso River, Hordaland, Modalen. } 2 \text { C. }\end{array}$ & $60^{\circ} 50.11^{\prime} \mathrm{N}, 06^{\circ} 19.48^{\prime} \mathrm{E}$ \\
\hline 22 & $16-\mathrm{V}-2002$ & $\begin{array}{l}\text { Small stream under Rt. E16 W of Voss. Hordaland, } \\
\text { Modalen. } 6.5 \text { C. }\end{array}$ & $60^{\circ} 37.52^{\prime} \mathrm{N}, 06^{\circ} 23.65^{\prime} \mathrm{E}$ \\
\hline 23 & $16-\mathrm{V}-2002$ & $\begin{array}{l}\text { Very small stream across road leading to Eksinge- } \\
\text { dal, Teigdal Valley. Hordaland, Modalen. } 7 \text { C. }\end{array}$ & $60^{\circ} 40.39^{\prime} \mathrm{N}, 06^{\circ} 05.47^{\prime} \mathrm{E}$ \\
\hline 24 & $16-\mathrm{V}-2002$ & $\begin{array}{l}\text { Teigdal Elva, main river of Teigdal Valley. Horda- } \\
\text { land, Modalen. } 5 \text { C. }\end{array}$ & $60^{\circ} 41.92^{\prime} \mathrm{N}, 06^{\circ} 06.66^{\prime} \mathrm{E}$ \\
\hline 25 & $16-\mathrm{V}-2002$ & $\begin{array}{l}\text { Swampy pool next to Teigdal elva. Hordaland, } \\
\text { Modalen. } 9 \text { C. }\end{array}$ & $60^{\circ} 41.92^{\prime} \mathrm{N}, 06^{\circ} 06.66^{\prime} \mathrm{E}$ \\
\hline 26 & $16-\mathrm{V}-2002$ & $\begin{array}{l}\text { Drainage ditch on } \mathrm{E} \text { side of road near bridge, } \mathrm{S} \text { of } \\
\text { Teigdal Valley pass. Hordaland, Modalen. } 1 \mathrm{C} \text {. }\end{array}$ & $60^{\circ} 45.27^{\prime} \mathrm{N}, 06^{\circ} 07.90^{\prime} \mathrm{E}$ \\
\hline 28 & $18-\mathrm{V}-2002$ & $\begin{array}{l}\text { Drainage ditch on } \mathrm{E} \text { side of road near bridge, } \mathrm{S} \text { of } \\
\text { Teigdal Valley pass. Hordaland, Modalen. } 4 \mathrm{C} \text {. }\end{array}$ & $60^{\circ} 45.27^{\prime} \mathrm{N}, 06^{\circ} 07.90^{\prime} \mathrm{E}$ \\
\hline 30 & $18-\mathrm{V}-2002$ & $\begin{array}{l}\text { Stream at bottom of Haga foss, a tributary of the } \\
\text { Ekso River. Hordaland, Modalen. } 4 \text { C. }\end{array}$ & $60^{\circ} 50.11^{\prime} \mathrm{N}, 06^{\circ} 19.48^{\prime} \mathrm{E}$ \\
\hline 31 & $20-\mathrm{V}-2002$ & $\begin{array}{l}\text { River Teigdal Elva, main river of Teigdal Valley. } \\
\text { Hordaland, Modalen. } 6 \text { C. }\end{array}$ & $60^{\circ} 41.92^{\prime} \mathrm{N}, 06^{\circ} 06.66^{\prime} \mathrm{E}$ \\
\hline 32 & 20-V-2002 & $\begin{array}{l}\text { Swampy pool next to River Teigdal Elva. Horda- } \\
\text { land, Modalen. } 14 \text { C. }\end{array}$ & $60^{\circ} 41.92^{\prime} \mathrm{N}, 06^{\circ} 06.66^{\prime} \mathrm{E}$ \\
\hline 33 & $20-\mathrm{V}-2002$ & $\begin{array}{l}\text { Drainage ditch on } \mathrm{E} \text { side of road near bridge, } \mathrm{S} \text { of } \\
\text { Teigdal Valley pass. Hordaland, Modalen. 2.5 C. }\end{array}$ & $60^{\circ} 45.27^{\prime} \mathrm{N}, 06^{\circ} 07.90^{\prime} \mathrm{E}$ \\
\hline 34 & 18-VIII-2002 & Seep cliff S of Dombås. Oppland, Dovre. 17 C. & $61^{\circ} 52.62^{\prime} \mathrm{N}, 09^{\circ} 25.28^{\prime} \mathrm{E}$ \\
\hline 35 & 18-VIII-2002 & $\begin{array}{l}\text { Tributary near junction of Kanten Rd. and Kongs- } \\
\text { vegen Rd., N of Dovre and E of Rt. E6. Opp- } \\
\text { land, Dovre. } 14.5 \text { C. }\end{array}$ & $61^{\circ} 59.61^{\prime} \mathrm{N}, 09^{\circ} 14.23^{\prime} \mathrm{E}$ \\
\hline
\end{tabular}


TABLE I. Continued

\begin{tabular}{|c|c|c|c|}
\hline Site & Date & Site description, County, Municipality & Latitude/Longitude \\
\hline 36 & 19-VIII-2002 & $\begin{array}{l}\text { Small stream crossing Rt. E6 in Dovre mountain } \\
\text { area. Oppland, Dovre. } 14.5 \text { C. }\end{array}$ & $62^{\circ} 05.70^{\prime} \mathrm{N}, 09^{\circ} 12.87^{\prime} \mathrm{E}$ \\
\hline 38 & 21-VIII-2002 & $\begin{array}{l}\text { Rock pool in Bølareinens park, off Rt. 763. Nord- } \\
\text { Trøndelag, Steinkjer. } 17 \text { C. }\end{array}$ & $64^{\circ} 08.77^{\prime} \mathrm{N}, 11^{\circ} 56.38^{\prime} \mathrm{E}$ \\
\hline 40 & 21-VIII-2002 & $\begin{array}{l}\text { Geritbekken River, a tributary of Jørstadelva on } \\
\text { road S off Hyw. 763. Nord-Trøndelag, Snåsa. } 17 \\
\text { C. }\end{array}$ & $64^{\circ} 10.86^{\prime} \mathrm{N}, 12^{\circ} 17.07^{\prime} \mathrm{E}$ \\
\hline 41 & 21-VIII-2002 & $\begin{array}{l}\text { Jørstadelva River SE of Site } 40 . \text { Nord-Trøndelag, } \\
\text { Snåsa. } 20 \text { C. }\end{array}$ & $64^{\circ} 09.61^{\prime} \mathrm{N}, 12^{\circ} 25.24^{\prime} \mathrm{E}$ \\
\hline 42 & 21-VIII-2002 & $\begin{array}{l}\text { Grana River, S of Snåsa, downstream from bridge. } \\
\text { Nord-Trøndelag, Snåsa. 11.5 C. }\end{array}$ & $64^{\circ} 14.25^{\prime} \mathrm{N}, 12^{\circ} 22.41^{\prime} \mathrm{E}$ \\
\hline 45 & 23-VIII-2002 & $\begin{array}{l}\text { Lake Snåsavatnet rocky bottom near shoreline. } \\
\text { Nord-Trøndelag, Snåsa. } 21.5 \text { C. }\end{array}$ & $64^{\circ} 07.65^{\prime} \mathrm{N}, 11^{\circ} 45.44^{\prime} \mathrm{E}$ \\
\hline $45 \mathrm{~A}$ & 23-VIII-2002 & $\begin{array}{l}\text { Rock pool above shoreline of Site } 45 \text {. Nord-Trøn- } \\
\text { delag, Snåsa. }\end{array}$ & $64^{\circ} 07.65^{\prime} \mathrm{N}, 11^{\circ} 45.44^{\prime} \mathrm{E}$ \\
\hline 46 & 23-VIII-2002 & $\begin{array}{l}\text { Seepy cliff on S side of Rt. } 74 \text {. Nord-Trøndelag, Li- } \\
\text { erne. }\end{array}$ & $64^{\circ} 28.14^{\prime} \mathrm{N}, 12^{\circ} 54.20^{\prime} \mathrm{E}$ \\
\hline 51 & 23-VIII-2002 & $\begin{array}{l}\text { Djubvasselva stream connecting lake Djupvatnet } \\
\text { and lake Laksjøen. Nord-Trøndelag, Lierne. } 20 \\
\text { C. }\end{array}$ & $64^{\circ} 26.08^{\prime} \mathrm{N}, 13^{\circ} 36.93^{\prime} \mathrm{E}$ \\
\hline 52 & 23-VIII-2002 & $\begin{array}{l}\text { Stream draining lake } 491 \text { at } \varnothing \mathrm{kstjorna} W \text { of Rt. } \\
\text { 765. Nord-Trøndelag, Lierne. }\end{array}$ & $64^{\circ} 21.70^{\prime} \mathrm{N}, 13^{\circ} 37.29^{\prime} \mathrm{E}$ \\
\hline 53 & 23-VIII-2002 & $\begin{array}{l}\text { Aunelva stream draining S. Nord-Trøndelag, } \\
\text { Steinkjer. } 17.5 \text { C. }\end{array}$ & $64^{\circ} 19.66^{\prime} \mathrm{N}, 13^{\circ} 35.52^{\prime} \mathrm{E}$ \\
\hline 54 & 28-VIII-2002 & $\begin{array}{l}\text { Small stream crossing Rt. } 759 \text {, SSE of Steinkjer. } \\
15.5 \text { C. }\end{array}$ & $63^{\circ} 57.64^{\prime} \mathrm{N}, 11^{\circ} 34.27^{\prime} \mathrm{E}$ \\
\hline 56 & 28-VIII-2002 & $\begin{array}{l}\text { Very small waterfall on E side of Rt. } 759 . \text { Nord- } \\
\text { Trøndelag, Steinkjer. } 13 \text { C. }\end{array}$ & $63^{\circ} 48.74^{\prime} \mathrm{N}, 11^{\circ} 35.32^{\prime} \mathrm{E}$ \\
\hline 57 & 28-VIII-2002 & $\begin{array}{l}\text { Large waterfall, Kjaekerfossen, just off Rt. } 757 . \\
\text { Nord-Trøndelag, Steinkjer. } 18.5 \text { C. }\end{array}$ & $63^{\circ} 50.25^{\prime} \mathrm{N}, 12^{\circ} 01.68^{\prime} \mathrm{E}$ \\
\hline 58 & 28-VIII-2002 & $\begin{array}{l}\text { Pools on shore of Verbalselva at Vuku, E of bridge } \\
\text { crossing river to Stene at Rt. } 758 \text { off of Rt. } 757 \text {. } \\
\text { Nord-Trøndelag, Steinkjer. } 20-21.5 \text { C. }\end{array}$ & $63^{\circ} 46.53^{\prime} \mathrm{N}, 11^{\circ} 43.96^{\prime} \mathrm{E}$ \\
\hline 59 & 28-VIII-2002 & $\begin{array}{l}\text { Rock pool in Bølareinens park, off Rt. 763. Nord- } \\
\text { Trøndelag, Steinkjer. } 17 \text { C. }\end{array}$ & $64^{\circ} 08.77^{\prime} \mathrm{N}, 11^{\circ} 56.38^{\prime} \mathrm{E}$ \\
\hline 60 & 28-VIII-2002 & $\begin{array}{l}\text { Greitbekken River, a tributary of Jørstadelva on } \\
\text { road S off Hyw. 763. Nord-Trøndelag, Snåsa. }\end{array}$ & $64^{\circ} 10.86^{\prime} \mathrm{N}, 12^{\circ} 17.07^{\prime} \mathrm{E}$ \\
\hline 61 & 29-VIII-2002 & $\begin{array}{l}\text { Large waterfall, Kjaekerfossen, just off Rt. } 757 . \\
\text { Nord-Trøndelag, Steinkjer. 18.5 C. }\end{array}$ & $63^{\circ} 50.25^{\prime} \mathrm{N}, 12^{\circ} 01.68^{\prime} \mathrm{E}$ \\
\hline 62 & 29-VIII-2002 & $\begin{array}{l}\text { Pools on shore of Verbalselva at Vuku, E of bridge } \\
\text { crossing river to Stene at Rt. } 758 \text { off of Rt. } 757 \text {. } \\
\text { Nord-Trøndelag, Steinkjer. }\end{array}$ & $63^{\circ} 46.53^{\prime} \mathrm{N}, 11^{\circ} 43.96^{\prime} \mathrm{E}$ \\
\hline 63 & 29-VIII-2002 & $\begin{array}{l}\text { Lake Snåsavatnet rocky bottom near shoreline. } \\
\text { Nord-Trøndelag, Snåsa. }\end{array}$ & $64^{\circ} 07.65^{\prime} \mathrm{N}, 11^{\circ} 45.44^{\prime} \mathrm{E}$ \\
\hline
\end{tabular}

\section{NEW TAXA}

Ephemerellomyces M.M. White \& Lichtw., gen. nov. Trichosporae longi-ovoideae, appendicibus 2-3 perlongis praeditae, aliquando cum in cuticula proctodaei germinantes cellulam quae trichosporam unicam terminalem gerens producentes. In proctodaeo nympharum Ephemeropterorum affixus.

Trichospores long-ovoid with 2-3 long appendages. Trichospores may germinate on hindgut cuticle to produce a cell bearing one terminal trichospore. Attached to hindgut of Ephemeroptera nymphs. SPECIES TYPICA: Ephemerellomyces aquilonius M.M. White \& Lichtw.

Etymology. Fungus in species of the host genus Ephemerella.

Ephemerellomyces aquilonius M.M. White \& Lichtw., sp. nov.

FIGS. 1-6 

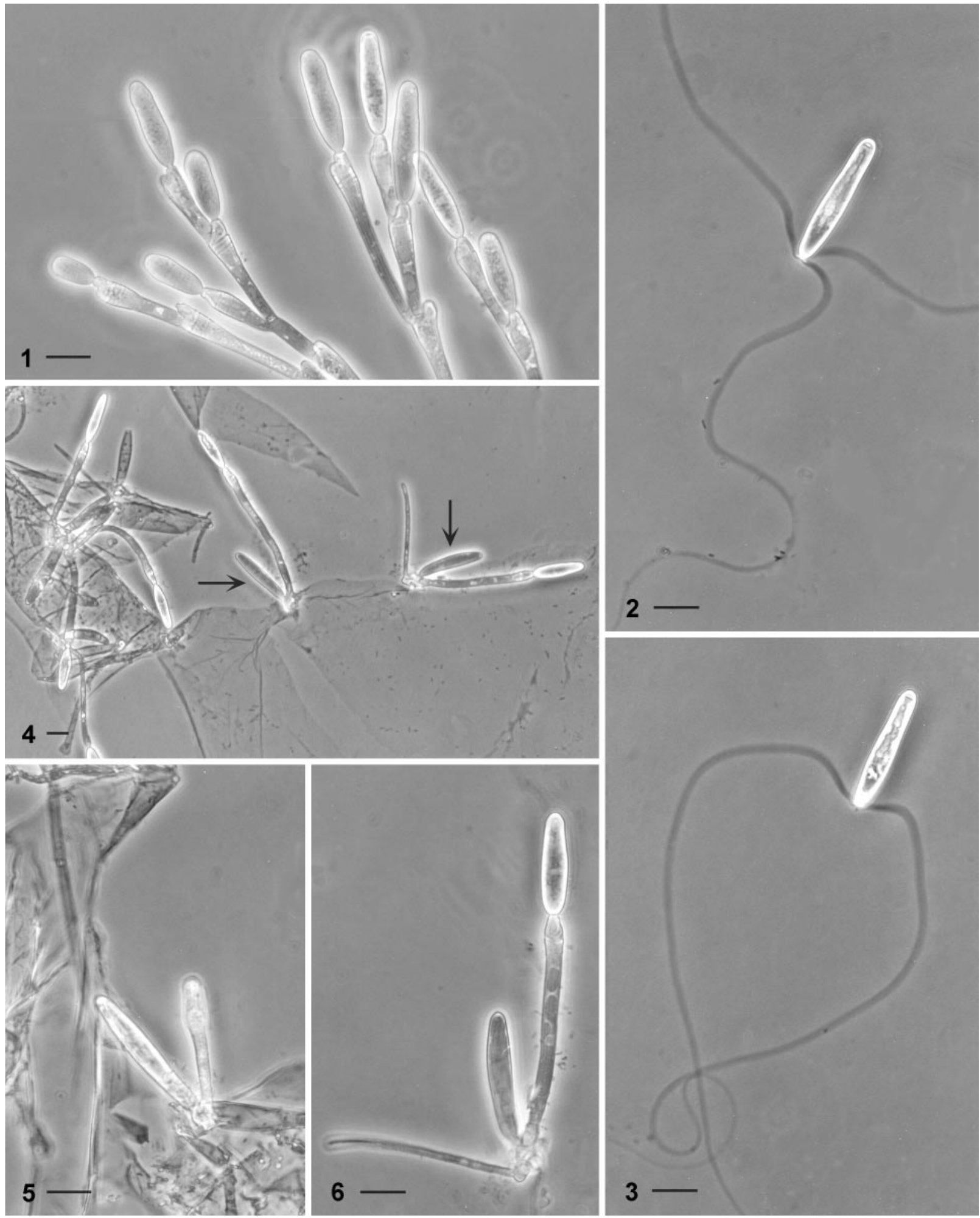

Figs. 1-6. Ephemerellomyces aquilonius from nymphs of Ephemerella aurivillii (Ephemeroptera: Ephemerellidae). 1. Branchlets producing trichospores (from a dissection designated [hereafter $=$ \#] NOR-57-W4). 2, 3. Released mature trichospores with three and two appendages, respectively (\# NOR-61-W3, \# NOR-57-W1). 4. Five germinated trichospores (arrows point to two) attached to the host's hindgut cuticle, each small thallus producing one terminal trichospore. 5. Early stage of trichospore germination; the trichospore is on the left. 6. Small sporulating thallus with a second branch at its base (enlargement of one shown in FIG. 4; FIGS. 4-6 are from \# NOR-61-W3). Scale bars $=20 \mu \mathrm{m}$. 
Trichosporae longi-ovoideae, (30-)45(-50) × 8-10 $\mu \mathrm{m}$, appendicibus 2 interdum 3 perlongis praeditae, aliquando in cuticula proctodaei affingentes et germinantes et cellulam 75-110 $\mu \mathrm{m}$ fertilem producentes quae trichosporam unicam terminalem gerens. Zygosporae ignotae. In proctodaeo nympharum Ephemeropterorum affixus.

Trichospores long-ovoid, (30-)45(-50) × 8-10 $\mu \mathrm{m}$, with 2 , occasionally 3 , long appendages. Trichospores sometime attach and germinate on the hindgut cuticle and produce a fertile cell 75-110 $\mu \mathrm{m}$ long bearing one terminal trichospore. Zygospores unknown. In hindgut of Ephemeroptera nymphs.

Etymology. L. aquilonius = northern.

Specimens examined. NORWAY. Large waterfall, Kjaekerfossen, just off Route $757.63^{\circ} 50.25^{\prime} \mathrm{N}, 12^{\circ} 01.68^{\prime} \mathrm{E}, 29-\mathrm{VIII}-$ 2002. Microscope slide NOR-61-W3 (HOLOTYPE: FH), in hindgut of Ephemerella aurivillii (Bengtsson) nymph (Ephemeroptera) from Site 61 (TABLE I); microscope slide NOR-57-W1 (PARATYPE: FH) in same host species from Site 57. Other collections from sites 40, 57, 61.

The type of trichospore germination (FIGS. 4-6) by attachment to the hindgut lining and production of a single trichospore has not been found in any other genus. Also, the production of 2 or 3 trichospore appendages (FIGS. 2, 3) is unique to this new genus. Otherwise, the trichospores resemble those in the 2appendaged genera Genistelloides Peterson, Lichtw. \& Horn and Legeriomyces Pouzar.

Genistelloides amplispora M.M. White \& Lichtw., sp. nov. Figs. 7-9

Trichosporae longi-ellipsoidales, 50-60 × 9-10 $\mu \mathrm{m}$. Zygosporae biconicae (Typus I) 26-28 $\times 4-4.5 \mu \mathrm{m}$; zygosporophora $17-20 \times 4-5 \mu \mathrm{m}$. In proctodaeo nympharum Nemouridarum (Plecopterorum) affixa.

Trichospores long-ellipsoidal, 50-60 × 9-10 $\mu \mathrm{m}$. Biconical zygospores (Type I) 26-28 × 4-4.5 $\mu \mathrm{m}$, zygosporophores $17-20 \times 4-5 \mu \mathrm{m}$. In hindgut of Nemouridae (Plecoptera) nymphs.

Etymology. L. amplus = large.

Specimens examined. Stream at bottom of Hagafoss, a tributary of the Ekso River, $60^{\circ} 50.11^{\prime} \mathrm{N}, 06^{\circ} 19.48^{\prime} \mathrm{E}, 15-\mathrm{V}-2002$. FIG. 9 (HOLOTYPE: FH), a photomicrograph of living zygospores from microscope slide NOR-19-W3, prepared from the hindgut of an Amphinemura sulcicollis (Stephens) nymph (Plecoptera: Nemouridae) from Site 19 (TABLE I). FIG. 8 (ISOTYPE: FH), a photomicrograph of a living trichospore from microscope slide NOR-21-W19A, from the same collection locality and host species as the holotype.

The mature trichospores of G. amplispora were not found released, and therefore appendages were not observed. However, within the generative cell the appearance of the appendages is identical to 2-appendaged attached trichospores of other species (cf. FIGS. 8 and 11). Zygospores of the new species are of the same type, general appearance and approximate

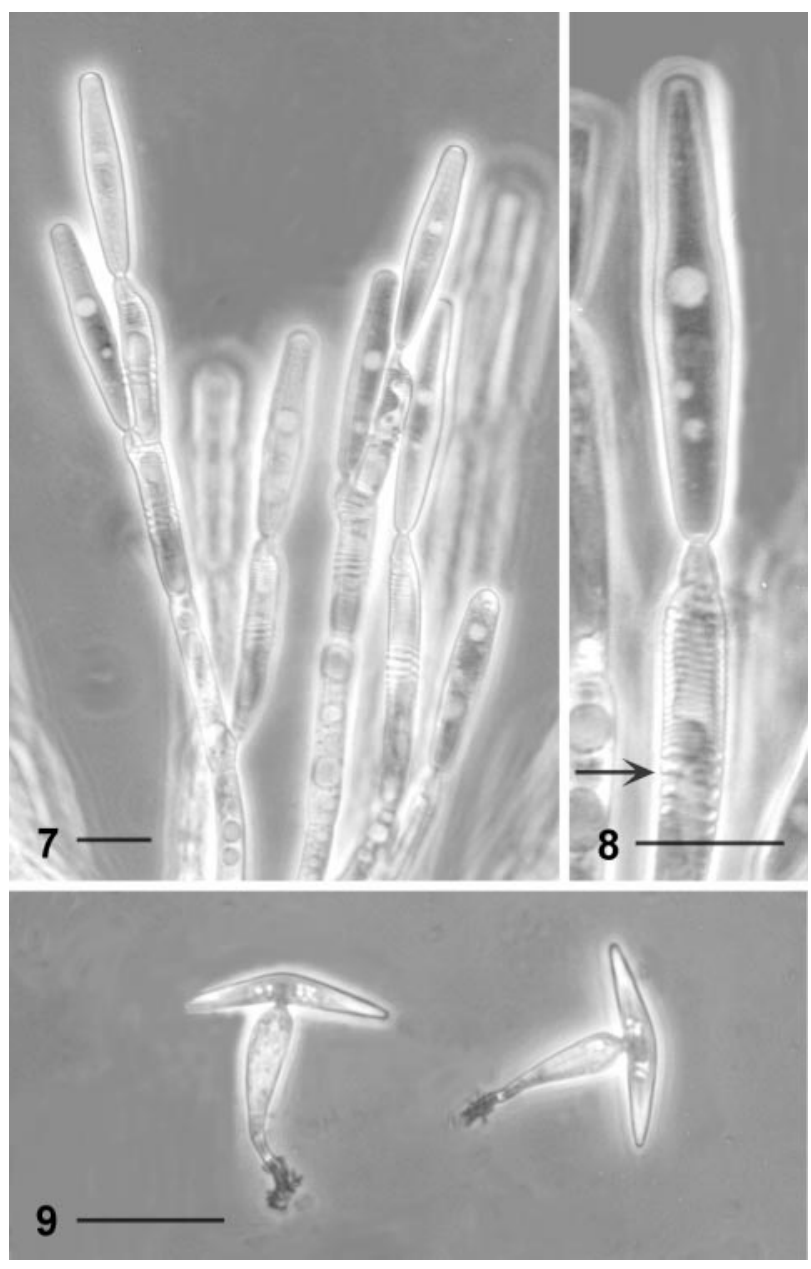

FIGS. 7-9. Genistelloides amplispora from nymphs of Amphinemura sulcicollis (Plecoptera: Nemouridae). 7, 8. Trichospores; note appendages within generative cell (arrow) (\# NOR-21-W19A). 9. Detached biconical zygospores with their attached zygosporophores (\# NOR-21-W3). Scale bars $=20 \mu \mathrm{m}$.

size as the type species, G. hibernus Peterson, Lichtw. \& Horn (Peterson et al 1981). Despite the similarity in zygospores (Type I, Moss et al 1975) for both species, Genistelloides amplispora is separated from G. hibernus on the basis of much larger trichospores. Trichospores of $G$. amplispora are only slightly larger on the average $(50-60 \times 9-10 \mu \mathrm{m})$ than those of $G$. helicoides M.C. Williams \& Lichtw. (42-)51(-62) $\times$ (7.5-)8.7(-10) $\mu \mathrm{m}$ (Williams and Lichtwardt 1987a), but $G$. helicoides presents a slightly larger length to width ratio. Thus, trichospores of Genistelloides helicoides are narrower overall, compared to G. amplispora, and trichospores of the former are slightly wider below the middle. Although we have collected $G$. helicoides on a number of occasions in the Rocky Mountains of Colorado and eastward in the U.S.A., zygospores have never been seen. In the absence of 
zygospores, distinctions between G. amplispora and G. helicoides are not entirely conclusive. Therefore, we provide two additional criteria for separating the species at this time. First, host association segregates the fungal species inhabiting different stonefly families: G. hibernus, G. helicoides and G. amplispora are associated, respectively, with Capniidae, Nemouridae, and Amphinemouridae. Second, G. amplispora has been found in Europe, and the two other species are North American. We predict that zygospores ultimately will provide further support for separation of the two species.

Genistelloides communis M.M. White \& Lichtw., sp. nov. $\quad$ Figs. 10-13

Trichosporae longi-obpyriformes, 31-38 $\times 5.5-6.5 \mu \mathrm{m}$, sub remissione appendicibus 2 longis, primum spiralibus. Zygosporae ignotae. In proctodaeo nympharum Nemouridarum (Plecopterorum) affixa.

Trichospores long-obpyriform, 31-38 $\times$ 5.5-6.5 $\mu \mathrm{m}$, bearing two long, initially helical appendages upon release. Zygospores unknown. In hindgut of Nemouridae (Plecoptera) nymphs.

Etymology. L. communis = common.

Specimens examined. NORWAY. Very small stream on E edge of Ekse field station building, $60^{\circ} 49.77^{\prime} \mathrm{N}, 06^{\circ} 14.37^{\prime} \mathrm{E}$, 15-V-2002. Microscope slide NOR-20-1 (HOLOTYPE: FH), prepared from a nymph of Nemoura cinerea (Retzius) from Site 20 (TABLE I); the slide also contains thalli of Paramoebidium sp. (Amoebidiales). Microscope slide NOR-2-W1 (PARATYPE: FH) prepared from a Nemouridae nymph from Site 2. Other specimens collected from sites 2, 19, 20, 23 and 33.

The two pronounced appendages of G. communis that initially form a tight helix (FIGS. 12, 13) are similar to those of G. helicoides (Williams and Lichtwardt 1987a). Trichospore size ranges do not overlap. Zygospores are unknown for both species, and Type I (Moss et al 1975) zygospores will be required for both species to confirm their generic placement. See Discussion for further comments on the taxonomic placement of these species.

Glotzia stenospora M.M. White \& Lichtw., sp. nov. Figs. 14-16

Trichosporae cylindraceae, 60-68 × 3-5 $\mu \mathrm{m}$. Zygosporae (Typus II) 61-72 × 11-14 $\mu \mathrm{m}$; zygosporophora 30-38 $\times 8$ $10 \mu \mathrm{m}$. In proctodaeo nympharum Ephemeropterorum affixa.

Trichospores cylindrical, 60-68 × 3-5 $\mu \mathrm{m}$. Zygospores (Type II) 61-72 × 11-14 $\mu \mathrm{m}$. Zygosporophores $30-38 \times 8-10 \mu \mathrm{m}$. In hindgut of Ephemeroptera nymphs.

Etymology. Gr. stenos = narrow.

Specimens examined. NORWAY. Small unnamed stream

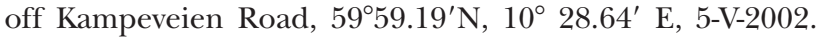
Microscope slide NOR-5-W17A (HOLOTYPE: FH), prepared from a Centroptilum luteolum (Müller) nymph (Ephemeroptera: Baetidae) from Site 5 (TABle I). Other specimen slides: NOR-5-W17B and NOR-5-W19.

Currently five other species of Glotzia have been described, four of them in nymphs of the mayfly family Baetidae, the exception being Glotzia plecopterorum Lichtwardt found in Gripopterygidae (Plecoptera) nymphs in New Zealand (Williams and Lichtwardt 1990). At Site 5 we collected a few nymphs of Baetis niger (L.), but G. stenospora was not found in that host species. The mayfly host C. luteolum is the same host in which the type species, G. centroptili Manier \& Lichtw., was discovered, but neither the trichospore nor zygospore dimensions match the new species (for $G$. centroptili: trichospores $40 \times 4 \mu \mathrm{m}$, zygospores $50-60 \times 15 \mu \mathrm{m})$. Glotzia stenospora has trichospores that are similar to those of G. coloradense Lichtw. \& M.C. Williams (in Williams and Lichtwardt 1987b), but zygospores of the new species are longer and wider and do not overlap in size.

Legeriosimilis europaeus M.M. White \& Lichtw., sp. nov. FIGS. 17-19

Trichosporae longi obpyriformes, 33-40 × 6-8 $\mu \mathrm{m}$, appendicibus 3 latis, structura gangylioidea per appendicem in parte mediana praeditis. Zygosporae (Typus II) $70-83 \times$ 11-13 $\mu \mathrm{m}$, zygosporophora circa $25-35 \times 9 \mu \mathrm{m}$. In proctodaeo nympharum Siphlonuridarum (Ephemeropterorum) affixa.

Trichospores long-obpyriform, 33-40 × 6-8 $\mu \mathrm{m}$, with 3 wide appendages with a knob-like structure part way down each appendage. Zygospores (Type II) 70-83 × 11-13 $\mu \mathrm{m}$, zygosporophores about 25-35 $\times$ $9 \mu \mathrm{m}$. In hindgut of Siphlonuridae (Ephemeroptera) nymphs.

Etymology. L. europaeus = of Europe.

Specimens examined. NORWAY. Dalbekken stream, $60^{\circ} 29.99^{\prime} \mathrm{N}, 10^{\circ} 08.00^{\prime} \mathrm{E}, 9-\mathrm{V}-2002$. Microscope slide NOR16-W6B (HOLOTYPE: FH), prepared from an Ameletus inopinatus Eaton nymph (Ephemeroptera: Siphlonuridae) from Site 16 (TABLE I). Additional specimens collected at sites 3, 11, 24, and 31, all in the same host species.

Legeriosimilis tricaudata M.C. Williams \& Lichtw., the type species, was described from another Ameletus species that was collected in the Colorado Rocky Mountains (Williams and Lichtwardt 1999). The zygospores of $L$. europaeus are considerably longer $(70-83 \mu \mathrm{m})$ than the type species $(52-58 \mu \mathrm{m})$, but there is a slight overlap in the trichospore dimensions (in L. tricaudata: [33-]47[-52] × [7-]9.5[-11] $\mu \mathrm{m}$ ). The trichospore appendage structure (see Fig. 18) in both species is remarkably similar. 

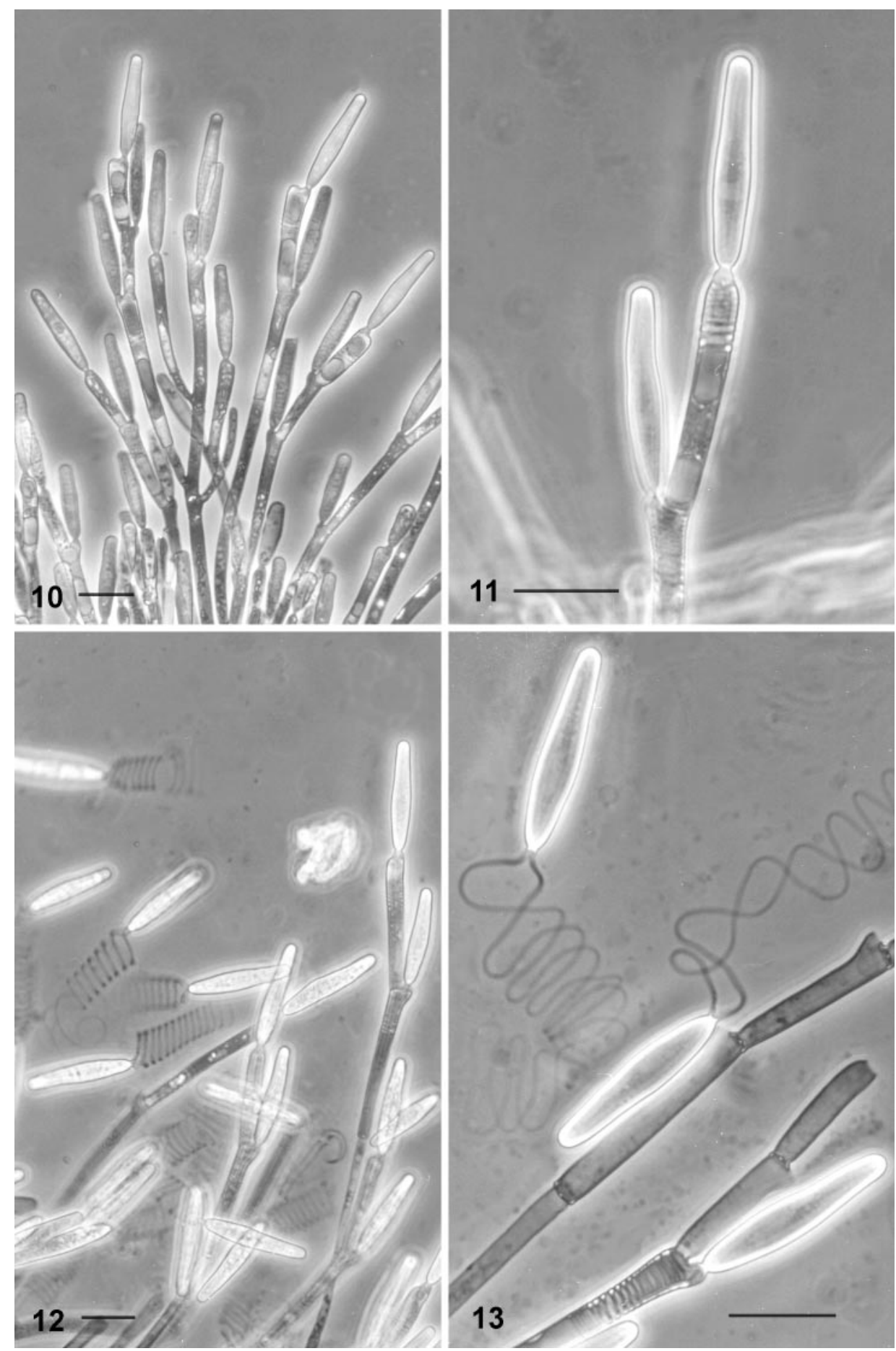

Figs. 10-13. Genistelloides communis from nymphs of Nemoura cinerea (Plecoptera: Nemouridae). 10, 11. Attached trichospores (\# NOR-19-W7, \# NOR-20-1). 12, 13. Newly released trichospores each bearing two appendages initially arranged in a helix (\# NOR-33-W11, \# NOR-2-W29). Scale bars $=20 \mu \mathrm{m}$. 

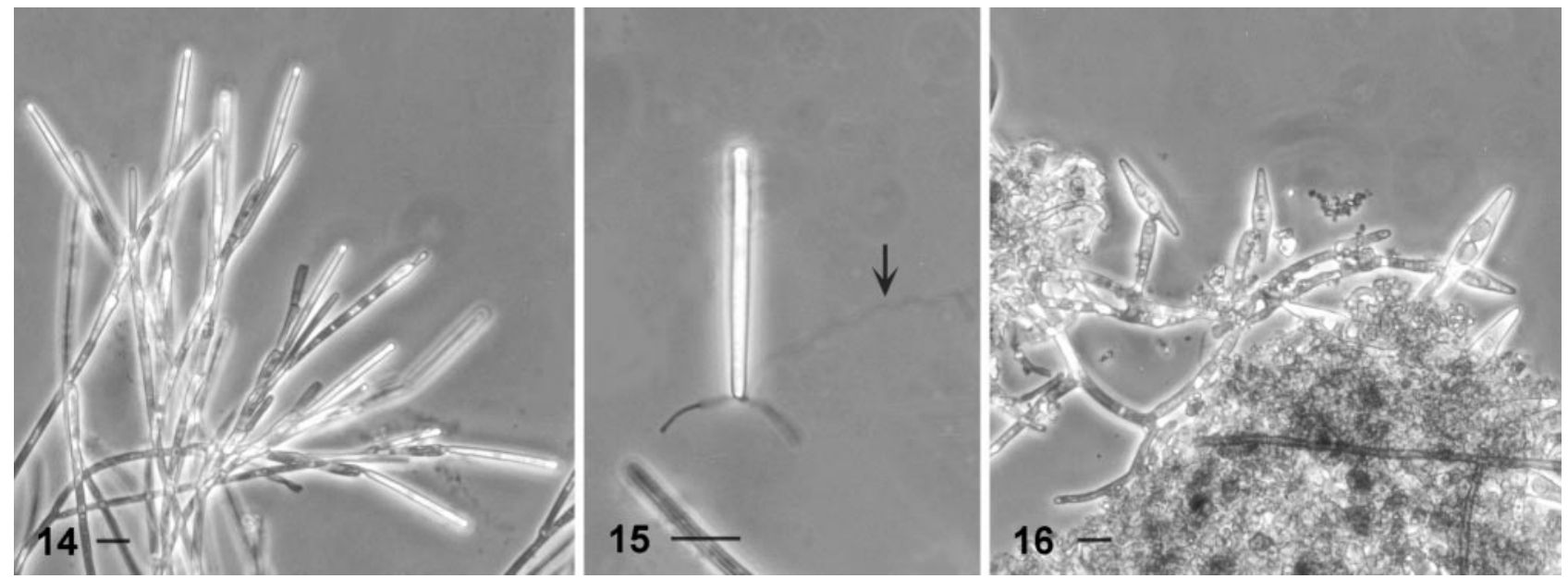

Figs. 14-16. Glotzia stenospora from nymphs of Centroptilum luteolum (Ephemeroptera: Baetidae). 14. Attached narrow trichospores (\# NOR-5-W17A). 15. Released trichospore with two short appendages and one almost invisible longer appendage (arrow) (\# NOR-5-W17A). 16. Biconical zygospores (\# NOR-5-W19). Scale bars $=20 \mu \mathrm{m}$.

Smittium biforme M.M. White \& Lichtw., sp. nov.

FIGS. 20-22

Thalli dimorphi, formas duas trichosporarum producentes, altera longi-ellipsoidalis, $34-42 \times 9-12 \mu \mathrm{m}$, collare campanulato, altera ovalis, $13-15 \times 6-7.5 \mu \mathrm{m}$, collare cylindra- ceo. Zygosporae biconicae (Typus II), 78-82 × 13-18 $\mu \mathrm{m}$. In proctodaeo larvarum Chironomidarum affixa.

Thalli dimorphic, producing two trichospore forms: long ellipsoidal trichospores, 34-42 × 9-12 $\mu \mathrm{m}$, with a campanulate collar; and oval trichospores, $13-15 \times$
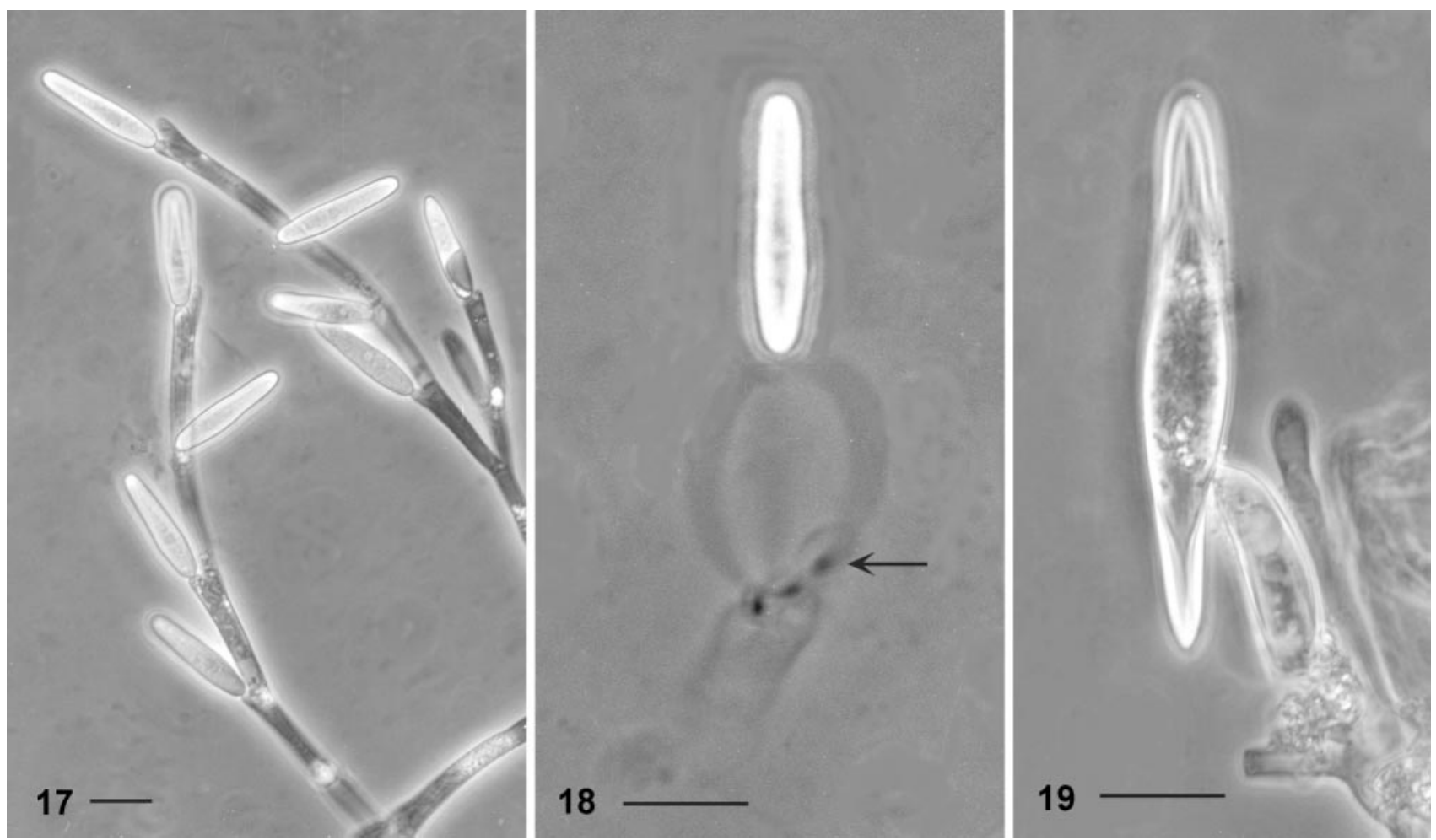

FIGS. 17-19. Legeriosimilis europaeus from nymphs of Ameletus inopinatus (Ephemeroptera: Siphlonuridae). 17, 18. Trichospores; upon release trichospores bear three diffuse appendages each with a dark knob-like structure (arrow points to one) part way down the appendage (\# NOR-24-2, \# NOR-2-W3). 19. Mature biconical zygospore (\# NOR-16-W6A). Scale bars $=20 \mu \mathrm{m}$. 


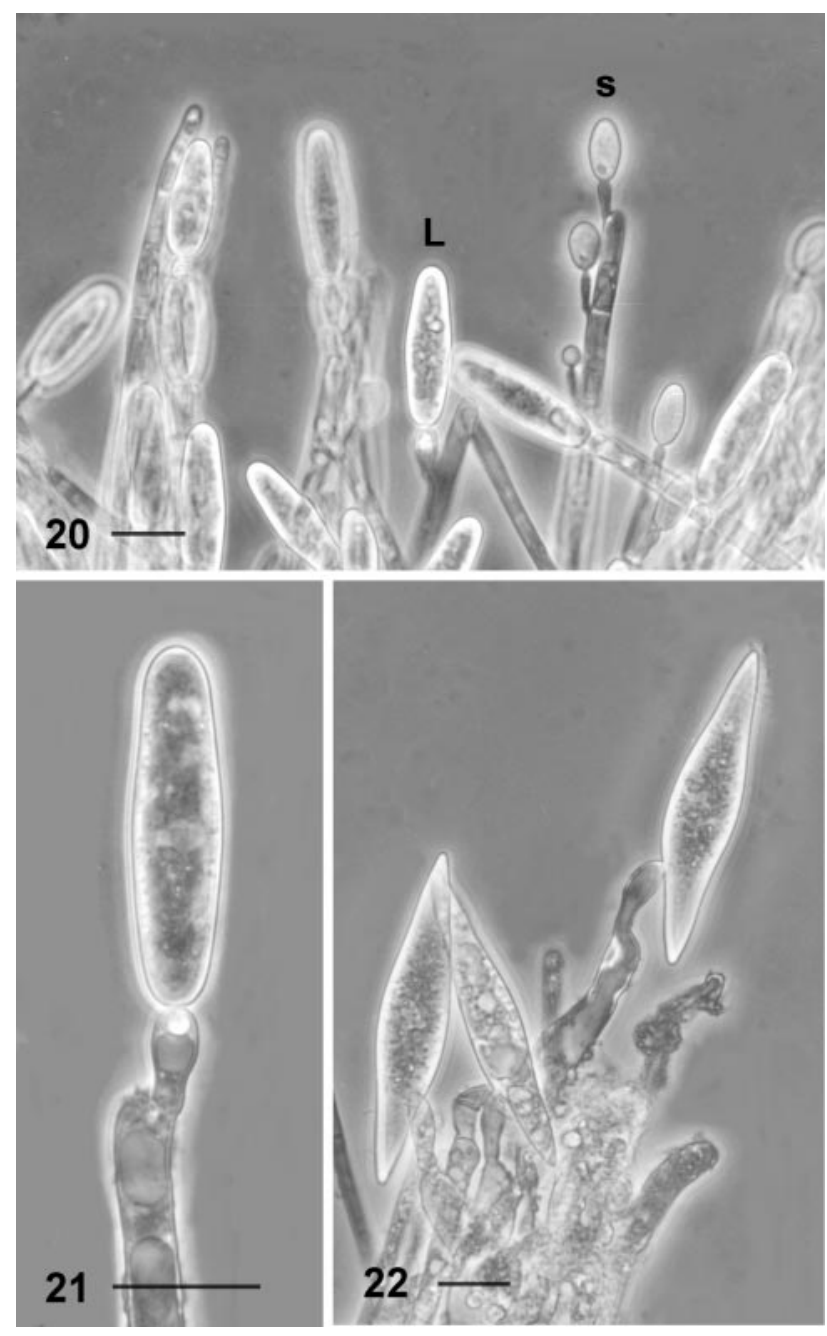

FIGS. 20-22. Smittium biforme from Diamesa aberrata larvae (Chironomidae: Diamesinae). 20. Branches of one thallus producing larger, long-ellipsoidal trichospores (L) and smaller, oval trichospores (s) (\# NOR-18-7). 21. A larger trichospore (\# NOR-18-W2). 22. Three zygospores (\# NOR18-W2). Scale bars $=20 \mu \mathrm{m}$.

6-7.5 $\mu \mathrm{m}$, with a cylindrical collar. Zygospores biconical (Type II), $78-82 \times 13-18 \mu \mathrm{m}$. In hindgut of Chironomidae larvae.

Etymology. L. bis, forma $=$ two shapes

Specimens examined. NORWAY. Seeping cliff on Route 7 at large parking area, $60^{\circ} 28.31^{\prime} \mathrm{N}, 09^{\circ} 56.68^{\prime} \mathrm{E}, 13-\mathrm{V}-2002$. Microscope slide NOR-18-7 (HOLOTYPE: FH) with two trichospore types; microscope slide NOR-18-W2 (ISOTYPE: FH) with zygospores, from Site 18 (TABLE I) in larvae of Diamesa aberrata Lundbeck and possibly D. bertrami Edwards (Chironomidae: Diamesinae).

Three other dimorphic Smittium spp. currently are described from either Diamesinae or Orthocladiinae larvae (Sm. dimorphum Lichtw. \& Williams, Sm. esteparum Lichtw. \& López Lastra, Sm. orthocladii Manier), but the combined dimensions of trichospores and zygospores do not match this new species (Lichtwardt et al 2001a). The other species have been found in France, U.S.A. and Argentina.

Smittium precipitiorum M.M. White \& Lichtw., sp. nov. FIGS. 23-25

Trichosporae ellipsoidales, $(13-) 17-22 \times 3.5-4.5 \mu \mathrm{m}$. Zygosporae $66-75 \times 10-13 \mu \mathrm{m}$. In proctodaeo larvarum Chironomidarum.

Trichospores ellipsoidal, (13-) 17-22 $\times$ 3.5-4.5 $\mu \mathrm{m}$. Zygospores 66-75 $\times 10-13 \mu \mathrm{m}$. In hindgut of Chironomidae larvae.

Etymology. L. precipitium = a cliff (for the seeping cliff where the species was found).

Specimens examined. NORWAY. Seeping cliff on Route 7, $11.5 \mathrm{~km}$ from Ørgenvika, Buskerud, Flå, $60^{\circ} 11.98^{\prime} \mathrm{N}$, $09^{\circ} 37.59^{\prime} \mathrm{E}, 13-\mathrm{V}-2002$. Microscope slide NOR-17-W7A (HOLOTYPE: FH) from Chironomidae larvae (both Orthocladius [Eudactylocladius] fuscimanus (Kieffer) and Diamesa cf. aberrata Lundbeck or Diamesa sp. have been identified from among the specimens dissected from this site) at Site 17 (TABLE I). The slide is one of three that include clumps of thalli removed from the guts of five larvae, all of which were infested with sporulating thalli. This slide also contains several clumps of thalli of Sm. culicis, which was actually more common at this site than $\mathrm{Sm}$. precipitiorum, as well as scattered smaller spores, perhaps from a third species (see FIG. 24). However, the slide includes two of five clusters of thalli that are clearly $\mathrm{Sm}$. precipitiorum on the basis of trichospore size and shape. Combined, these two clumps of thalli bear a total of 18 mature, attached zygospores (with maturity being measured by the wall thickness at the conical tips). The trichospore collar in $\mathrm{Sm}$. precipitiorum, which is short and exhibits some variability, was nearly campanulate in some instances, a shape that has been noted for the quite variable spores of $\mathrm{Sm}$. culicis. This new species description is justified on the basis of the zygospores and trichospores that clearly were evident on the two individual clumps of thalli.

Stachylina acutibasilaris M.M. White \& Lichtw., sp. nov. FiGS. 26-28

Thalli $78-155 \times 10-18 \mu \mathrm{m}$, cellula basali in haustorio parvo angustata, trichosporas 4 vel plus quam 8 producentes. Trichosporae ellipsoidales, in parte mediana subtumidae, collare carentes, 15-23 $\times 5-7 \mu \mathrm{m}$. Zygosporae ignotae. In membrana peritrophica larvarum Chironomidarum affixa.

Thalli $78-155 \times 10-18 \mu \mathrm{m}$, basal cell tapering to a small holdfast, producing 4-8 or more trichospores. Trichospores ellipsoidal with a slight median swelling, without a collar, 15-23 × 5-7 $\mu \mathrm{m}$. Zygospores unknown. Attached to peritrophic membrane of Chironomidae larvae.

Etymology. L. acutus, basilaris $=$ pointed at the base.

Specimens examined. NORWAY. Small stream crossing 

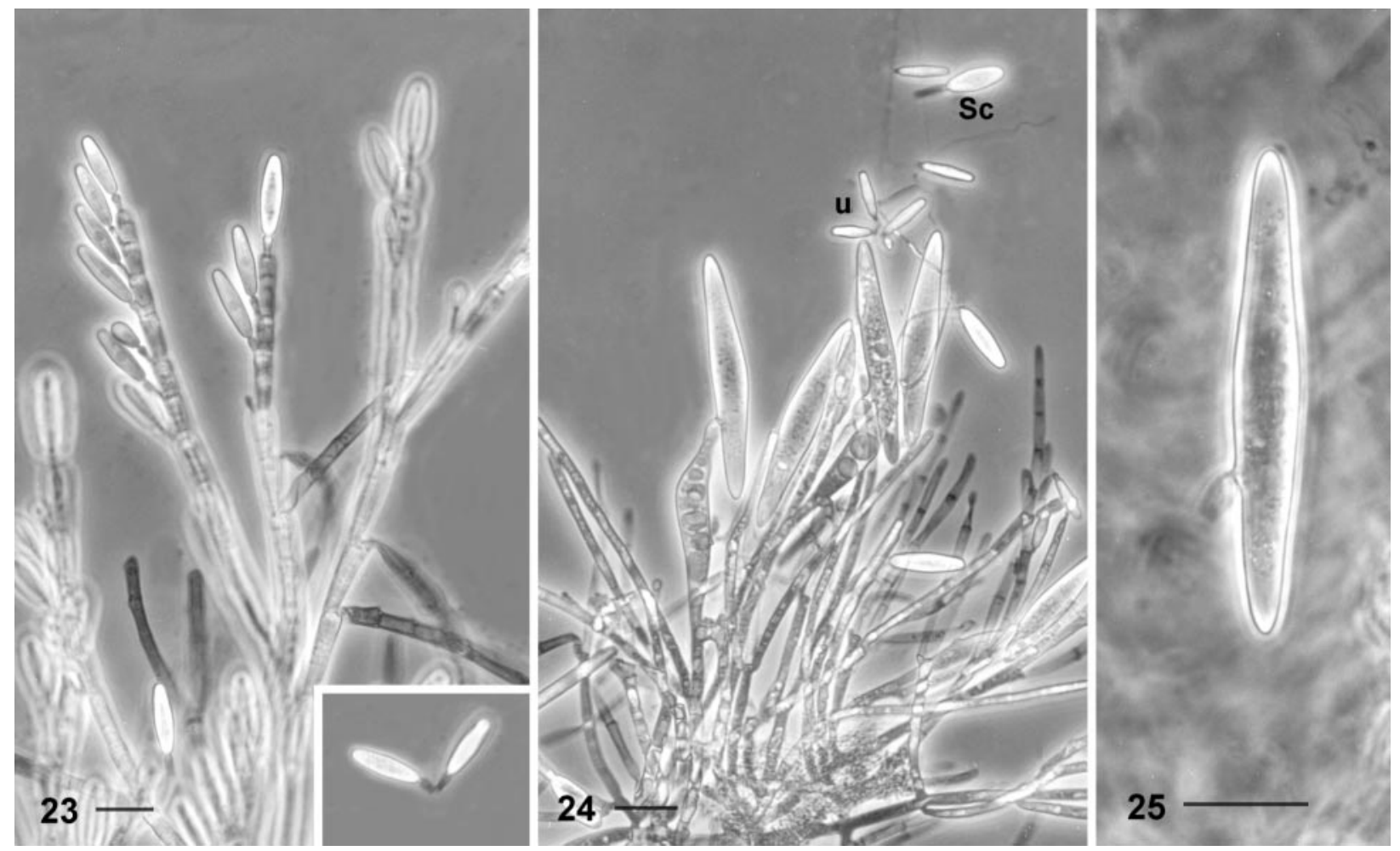

FIGS. 23-25. Smittium precipitiorum from Chironomidae larvae (Diptera). 23. Attached and (inset) released trichospores (\# NOR-17-4, \# NOR-17-2). 24. Zygospores and trichospores; this chironomid hindgut also contained Smittium culicis (Sc) and another, unidentified Smittium sp. (u) with smaller trichospores. (\# NOR-17-W7A) 25. Released zygospore with a collar (\# NOR-17-W7C). Scale bars $=20 \mu \mathrm{m}$.

Route 759 SSE of Steinkjer, $63^{\circ} 57.64^{\prime} \mathrm{N}, 11^{\circ} 34.27^{\prime} \mathrm{E}, 28-\mathrm{VIII}-$ 2002. Microscope slide NOR-54-W14 (HOLOTYPE: FH), prepared from a Brillia cf. longifurca Kieffer larva (Diptera: Chironomidae) collected from Site 54 (TABLE I).

This species is most similar to St. ceratopogonidarum Lichtw. \& Arenas, a species from Chilean Ceratopogonidae larvae, but the thalli of St. acutibasilaris are wider (10-18 versus 5-8 $\mu \mathrm{m})$

Stachylina lentica M.M. White \& Lichtw., sp. nov.

FiGS. 29-33

Thalli 50-150 × 4-9 $\mu \mathrm{m}$, base haustorio rotundato parvo, trichosporas 1-2(-4) producentes. Trichosporae longi-ellipsoideae, (22-) $35(-50) \times(4-) 5-6(-7) \mu \mathrm{m}$, collare brevissimo, appendice perlonga tenui. Zygosporae ignotae. In membrana peritrophica larvarum Chironomidarum affixa.

Thalli 50-150 × 4-9 $\mathrm{mm}$, with a small, rounded holdfast at the base, producing 1-2(-4) trichospores. Trichospores long-ellipsoidal, (22-) 35(-50) × (4-)5$6(-7) \mu \mathrm{m}$, with a very short collar, and a very long and fine appendage. Zygospores unknown. Attached to peritrophic membrane of Chironomidae larvae.

Etymology. L. lentus = slow (for the lentic habitat).

Specimens examined. NORWAY. Lake Snåsavatnet rocky bottom near shoreline, $64^{\circ} 07.65^{\prime} \mathrm{N}, 11^{\circ} 45.44^{\prime} \mathrm{E}$, 23-VIII2002. Microscope slide NOR-45-W1 (HOLOTYPE: FH), prepared from a Chironomus sp. larva (Chironomidae) from Site 45 (TABle I). Also from Site 45, in a larva of Brillia cf. longifurca Kieffer (Chironomidae) and in many larvae of Chironomus sp. from Site 58.

Twenty-two species of Stachylina have been described (Lichtwardt et al 2001a). Of these, St. lentica most closely resembles St. grandispora, a widespread species reported from Europe, U.S.A. and Australasia in various genera of Chironomidae larvae but most commonly in Chironomus spp. Several differences, however, are evident, leading us to describe the Norway species as new. Stachylina grandispora on the average has larger trichospores $(40-72 \times 6-10$ or more $\mu \mathrm{m})$, and thalli are generally longer and wider $(<100$ to $>250 \mu \mathrm{m}$ long by $6-10 \mu \mathrm{m}$ diam). Although St. grandispora rarely may have as few as two trichospores per thallus, more commonly it produces 4-16 trichospores. Thalli of St. lentica most commonly produce only 1-2 trichospores, and rarely 4 .

\section{POSSIBLE NEW SPECIES}

The following two species appear to be new but are not named here. We are furnishing descriptions and illustrations together with locations and hosts for future reference. 
Smittium sp. 1

Figs. 34-36

Larvae of Chironomus sp. from a rock pool at Site 38 had in their hindgut what appears to be an undescribed species of Smittium. Its diagnosis follows. Thallus base horseshoe-shaped, larger thalli may have verticillate branching, smaller thalli sparsely branched, 3-6 trichospores per branchlet. Branches 2-5 $\mu \mathrm{m}$ diam. Trichospores subcylindrical, 15-18 $\times$ 2-2.5 $\mu \mathrm{m}$.

\section{Smittium sp. 2}

Figs. 37-40

What appears to be another undescribed species of Smittium was found in the hindgut of an unusual range of hosts. These included Tipulidae larvae (Site 11), and Chironomidae larvae of Limnophyes sp. and Corynoneura cf. lobata Edwards (both Orthocladiinae) (Site 19) and Corynoneura sp. from Site 22. Larvae of Limnophyes and Corynoneura are minute, usually measuring only a few millimeters long. The diagnosis of this species follows. Colonies compact, producing ellipsoidal trichospores 9-13 $\times 3.5-4 \mu \mathrm{m}$, collar short up to $5 \mu \mathrm{m}$ long.

\section{PREVIOUSLY DESCRIBED SPECIES}

Graminella microspora S.T. Moss \& Lichtw.

Although not particularly common worldwide, $G$. microspora has a widespread distribution in Baetidae (Ephemeroptera), having been reported from the U.S.A., Switzerland, and southern Chile (Lichtwardt 1986, Lichtwardt and Arenas 1996). In Norway, the species was found at Site 35 in Baetis rhodani (Pictet). Though the specimens in our collection lacked zygospores, this species is easily identifiable by both the long series of minute collarless trichospores $(6-8.5 \times$ 2-2.5 $\mu \mathrm{m}$ ) with a single appendage and the peculiar bulbous outgrowths that detach from the thalli and produce new thalli vegetatively (see FIGS. 27-30 in Lichtwardt and Arenas 1996).

\section{Harpella melusinae Léger \& Duboscq}

Harpella melusinae is perhaps the most widely distributed species of Harpellales. It has been found attached to the peritrophic membrane (also known as the peritrophic matrix) in most populations of black fly larvae, which have been studied in many parts of the world, although currently it has not been collected in Central or South America where other species of Harpella are common. The species was found in almost all streams where Simuliidae were collected in Norway (sites 2, 4, 5, 7, 8, 11, 15, 16, 21, 22, 23, $26,28,33,36,42,51,52,53,54)$. The larval species included Prosimulium hirtipes (Fries), Eusimulium vernum (Macquart), Simulium monticola Friederichs,

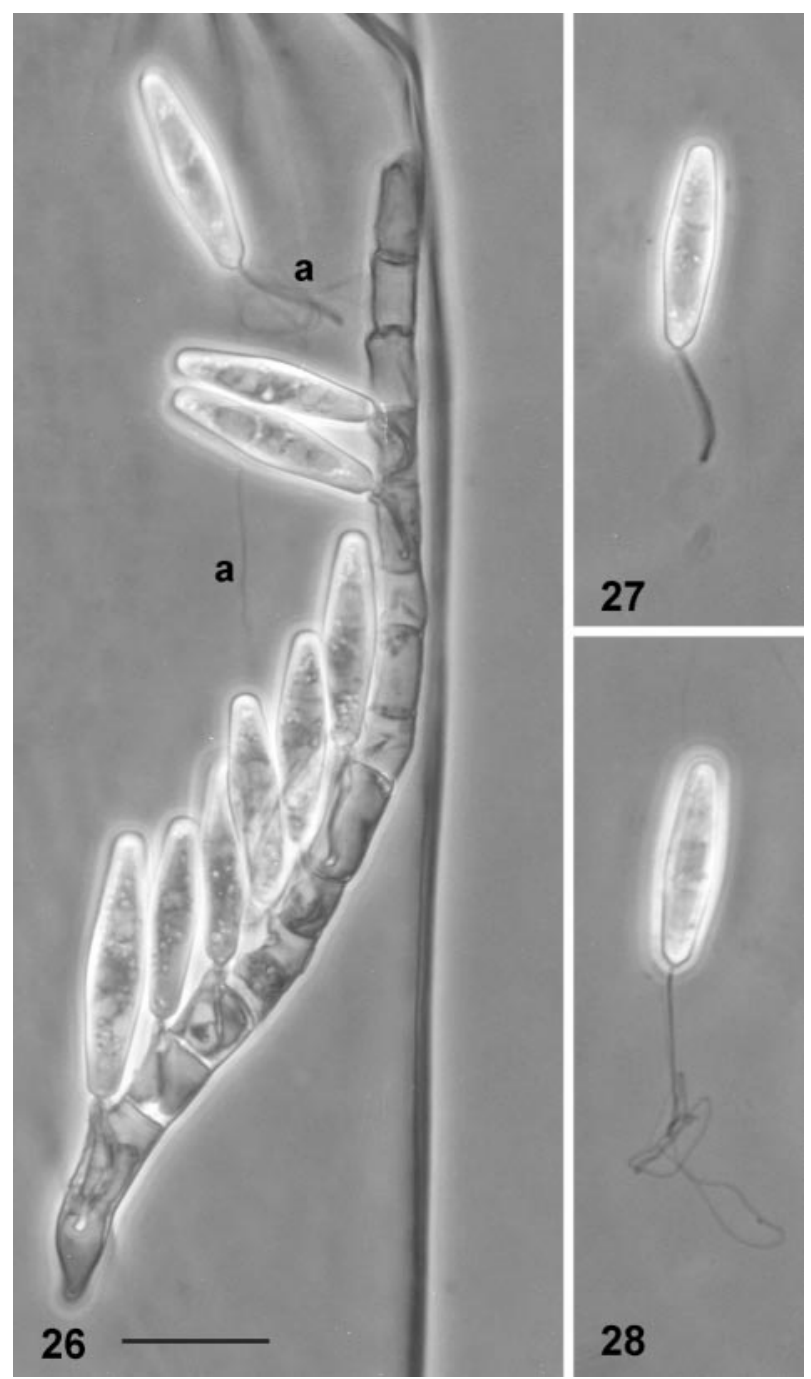

Figs. 26-28. Stachylina acutibasilaris from a Brillia cf. longifurca larva (Diptera: Chironomidae). 26. Entire thallus (composite of two photomicrographs) with attached and released trichospores as seen within the transparent peritrophic membrane; $\mathrm{a}=$ an extended appendage of one trichospore. 27. Trichospore with its single appendage as yet unfurled. 28. Trichospore with unfurling fine appendage. Scale bar $=20 \mu \mathrm{m}$ (\# NOR-54-W14).

S. ornatum Meigen, S. tuberosum (Lundström), and $S$. rotundatum (Rubzov).

\section{Harpellomyces eccentricus Lichtw. \& S.T. Moss}

Figs. 41-47

This type species originally was known only from Sweden and Wales in solitary midge larvae, Thaumalea spp. (Diptera: Thaumaleidae) (Lichtwardt and Moss 1984). Later, Santamaria and Girbal (1997) reported it from Thaumalea sp. in Spain. We obtained 

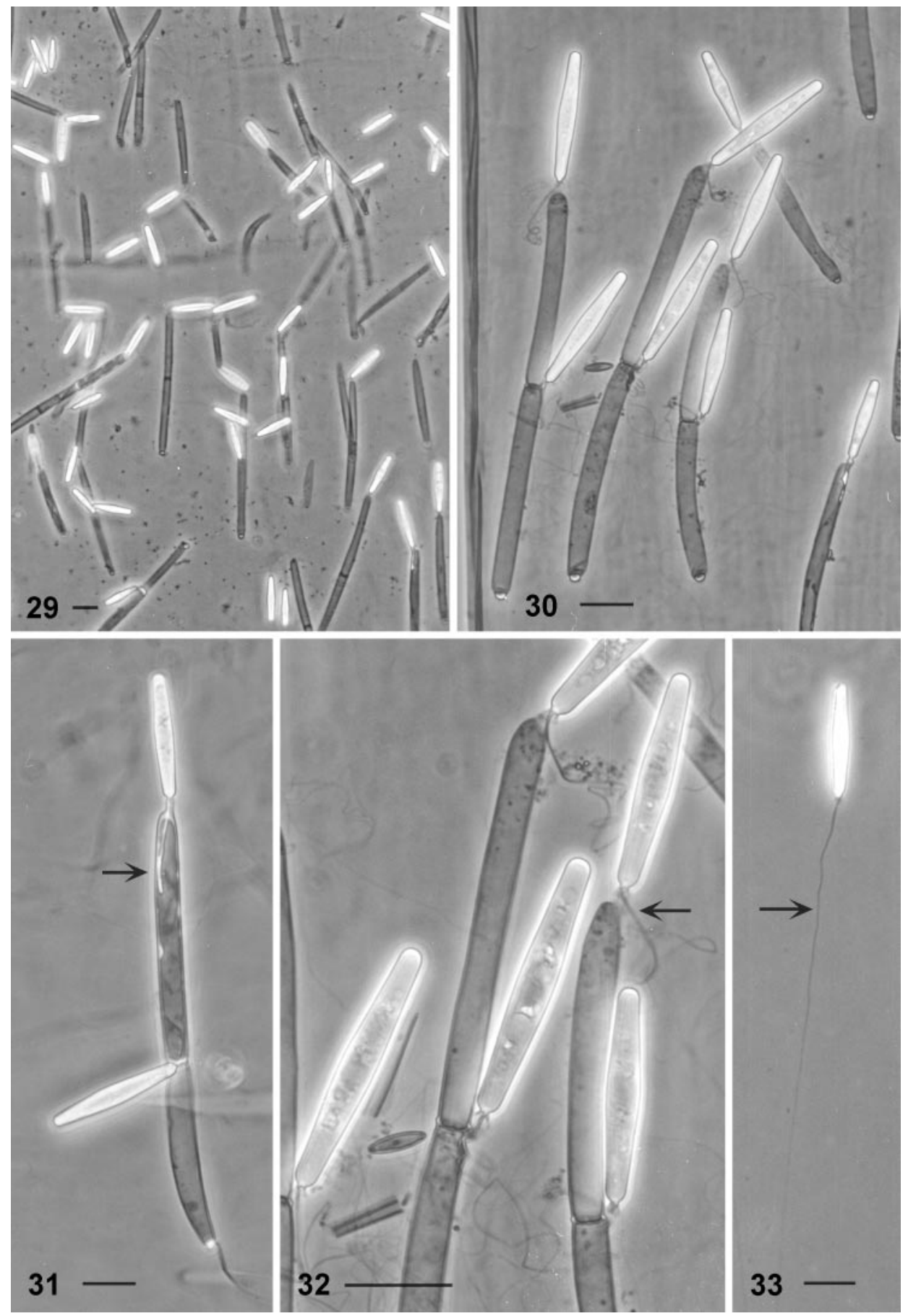

FIGS. 29-33. Stachylina lentica from a Chironomus sp. larva (Diptera: Chironomidae). 29, 30, 31. Unbranched sporulating thalli within the host's peritrophic membrane; arrow in FIG. 31 points to an appendage within a generative cell (\# NOR-5810, \# NOR34-W1, \# NOR-58-5). 32. Trichospores in the process of breaking away from the thallus with the appendage of each being released from the generative cell (arrow) (\# NOR-45-W1). 33. Trichospore with its very long, fine appendage (arrow) (\# NOR-45-W1). Scale bars $=20 \mu \mathrm{m}$.

sporulating specimens of $H$. eccentricus in larval Thaumalea sp. living in madicolous habitats (shallow sheets of water running or seeping down steep cliffs) at sites 34 and 56. The fungus probably is distributed more widely in Europe, but thaumaleids often have been overlooked as potential harpellid hosts. The only other species of Harpellomyces currently named is H. abruptus Lichtw., M.M. White \& Colbo collected from Thaumalea verralli Edwards larvae in Newfoundland, Canada (Lichtwardt et al 2001b). 

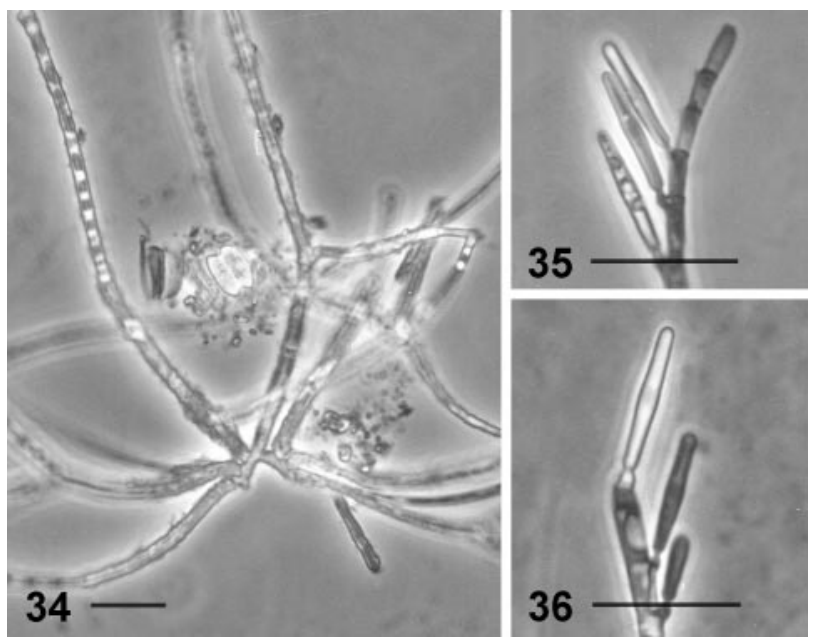

FigS. 34-36. Smittium sp. 1 from Chironomus sp. larvae (Diptera: Chironomidae). 34. Thallus with a horseshoeshaped holdfast cell at its base (\# NOR-38-15). 35, 36. Subcylindrical trichospores \# NOR-38-13, \# NOR-38-8). Scale bars $=20 \mu \mathrm{m}$.

\section{Legeriomyces ramosus Pouzar}

Legeriomyces ramosus first was discovered in France (Léger and Gauthier 1932), later in France, England, Switzerland, U.S.A. (Lichtwardt 1986) and more recently from Spain (Valle and Santamaria 2002). It is most common in Baetidae but also has been reported from another mayfly family, Ephemerellidae (Lichtwardt 1986). In Norway, both trichospores and zy- gospores of this species were found. It was no surprise to find this species in Baetis rhodani and also in a previously unrecorded mayfly host genus from Site 35, Siphlonurus (Siphlonuridae). Collections were obtained at sites $4,5,6,7$ and 35 .

Orphella catalaunica Santam. \& Girbal FIGS. 48-51

We found O. catalaunica at Norway sites 4, 9, 21, 28, 30, 33, 40 and 61 in Leuctra hippopus Kempny and probably other Leuctra spp. (Plecoptera: Leuctridae). It had been recorded originally from Spain in Leuctra sp. nymphs (Santamaria and Girbal 1998). Orphella is one of three genera of Harpellales whose mature thalli project from the anus of the host; consequently, often they can be seen with a stereo microscope before dissection. Our specimens conform well to the original description.

Orphella coronata Léger \& Gauthier

Figs. 52-55

This is the type species of the genus, but it has not been reported since the original publication (Léger and Gauthier 1931). The original description was incomplete, yet our specimens seem to be conspecific with Léger's and Gauthier's species, which they found living in Protonemura humeralis Pictet nymphs (Plecoptera: Nemouridae) in mountain streams of southeastern France. Our collections were from sites 4, 5, 10, 19 and 33. Hosts at most sites were Nemoura
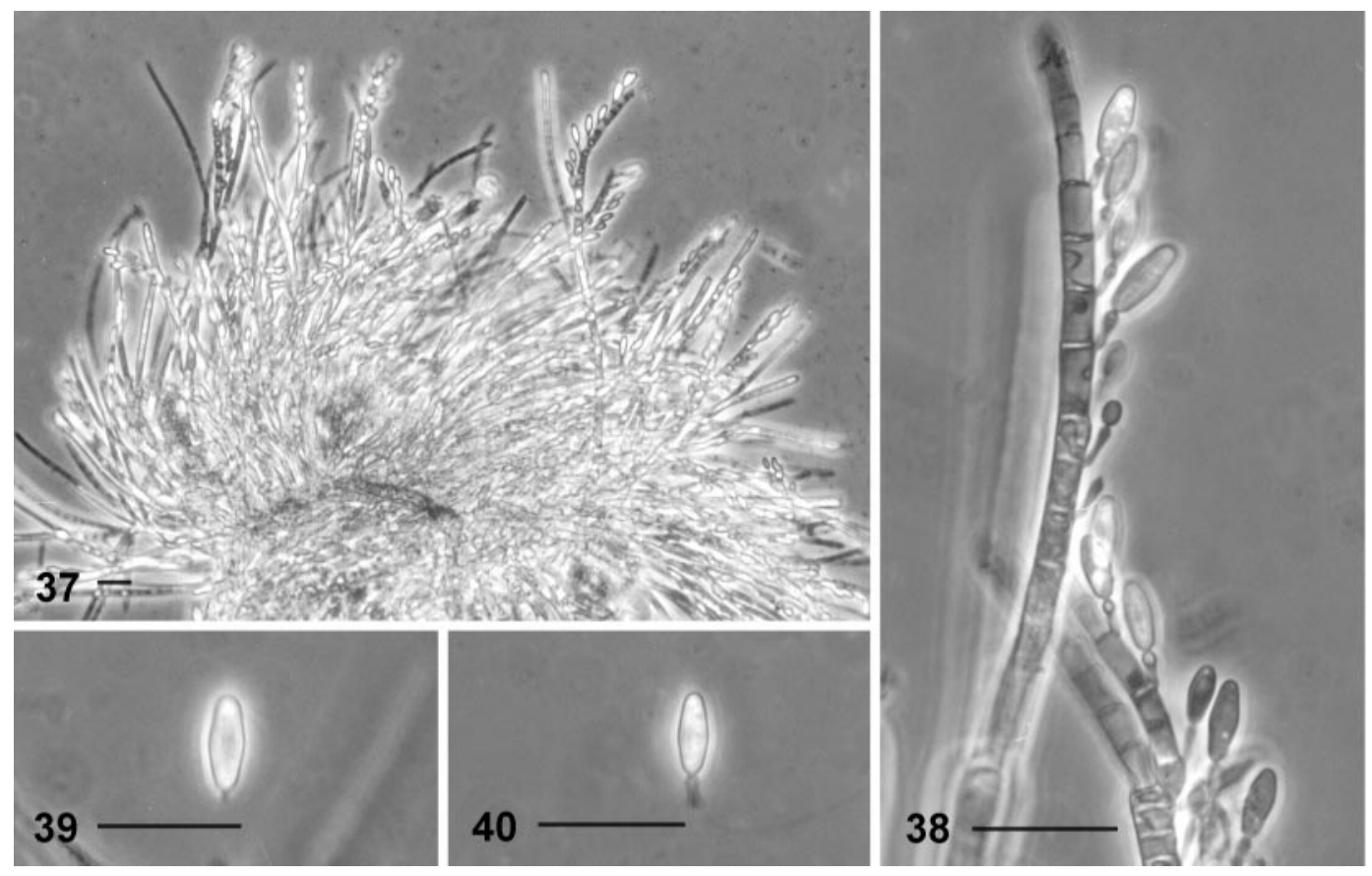

Figs. 37-40. Smittium sp. 2 from Chironomidae larvae (Diptera). 37. A dense, sporulating colony (\# NOR-19-4). 38. Attached trichospores (\# NOR-11-W21A). 39, 40. Released trichospores showing variation in overall size and collar lengths (\# NOR-22-7, \# NOR-11-W21A). Scale bars $=20 \mu \mathrm{m}$. 

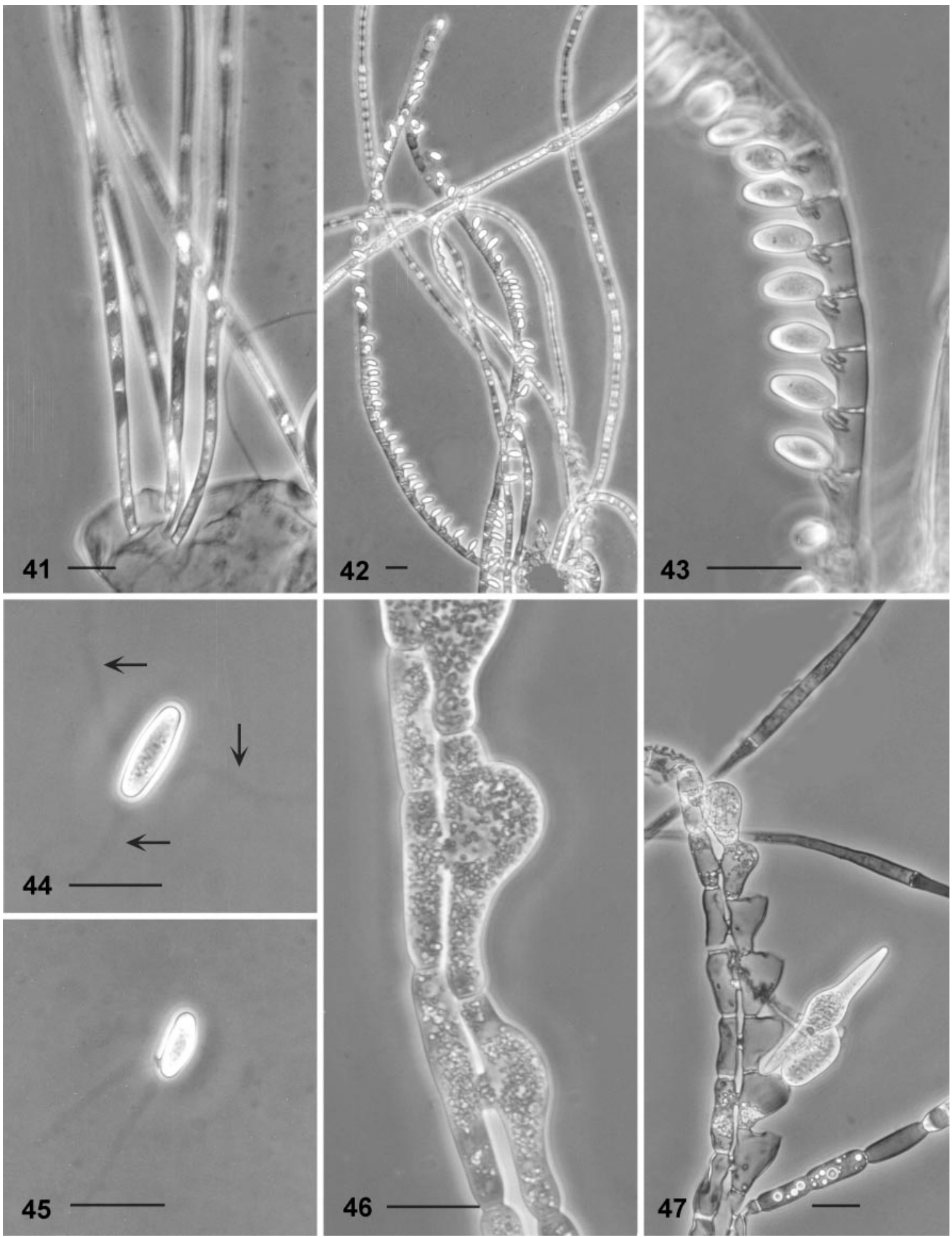

Figs. 41-47. Harpellomyces eccentricus from Thaumalea sp. larvae (Diptera: Thaumaleidae). 41. Unbranched bases of thalli with holdfasts attached to gut lining (\# NOR-34-5). 42, 43. Long series of trichospores developing on unbranched thalli (\# NOR-56-W2). 44. Released trichospore with three barely visible appendages (arrows) (\# NOR-34-W17A). 45. Trichospore with two appendages in focus showing the scar on lower left where it was attached to the generative cell (\# NOR-56-W2). 46. Two conjugating thalli with cells of one showing typical swollen structure that precedes zygospore formation (\# NOR-34W2). 47. Zygospore produced from a swollen conjugant cell (\# NOR-34-W2). Scale bars $=20 \mu \mathrm{m}$. 

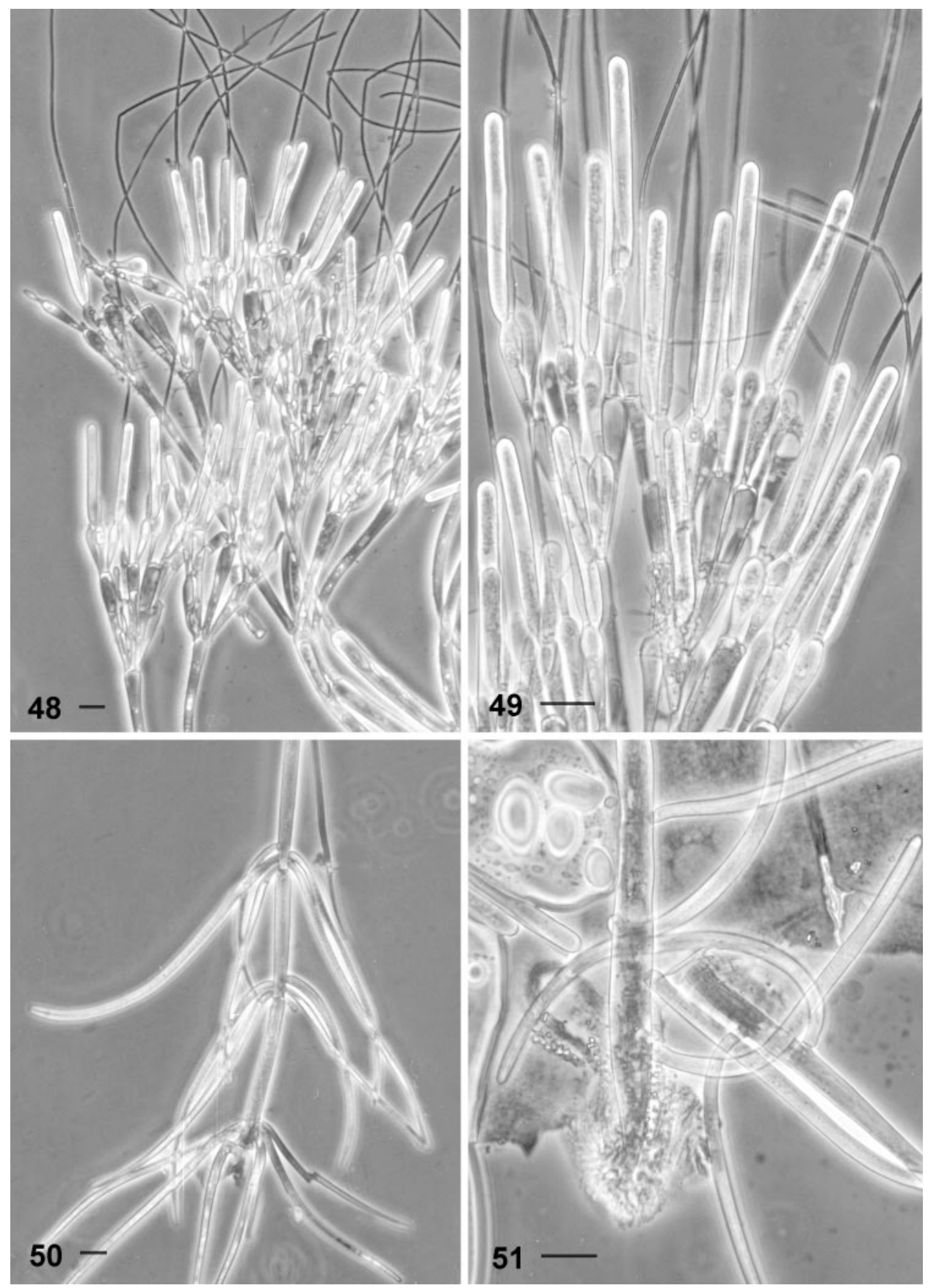

FIGS. 48-51. Orphella catalaunica from nymphs of Leuctra hippopus (Plecoptera: Leuctridae). 48, 49. Sporulating heads with cylindrical trichospores and long, filiform cells that constitute the terminal cell of the dissemination unit (\# NOR-19W2). 50, 51. Bases of thalli showing variation in the holdfast structure (\# NOR-61-W2, \# NOR-19-W1). Scale bars $=20 \mu \mathrm{m}$.

cinerea (Retzius), but in two collections (sites 4,5$)$ we found $O$. coronata in nymphs of Brachyptera rise (Morton) that belong to a different family of stoneflies, Taeniopterygidae.

Orphella helicospora Santam. \& Girbal Figs. 56-59 This is the second species of Orphella described by
Santamaria and Girbal (1998) from Spain, also in Leuctra sp. nymphs. Our collections of this species were found not only in Leuctra hippopus (Site 11) but also in Nemoura cinerea and N. nigra (Olivier) (sites 10, 19). The hindguts of some Nemoura nymphs also contained $O$. coronata. The very long, straight terminal cells of the dissemination units shown in Figs. 56-58 often were shorter in many thalli. 

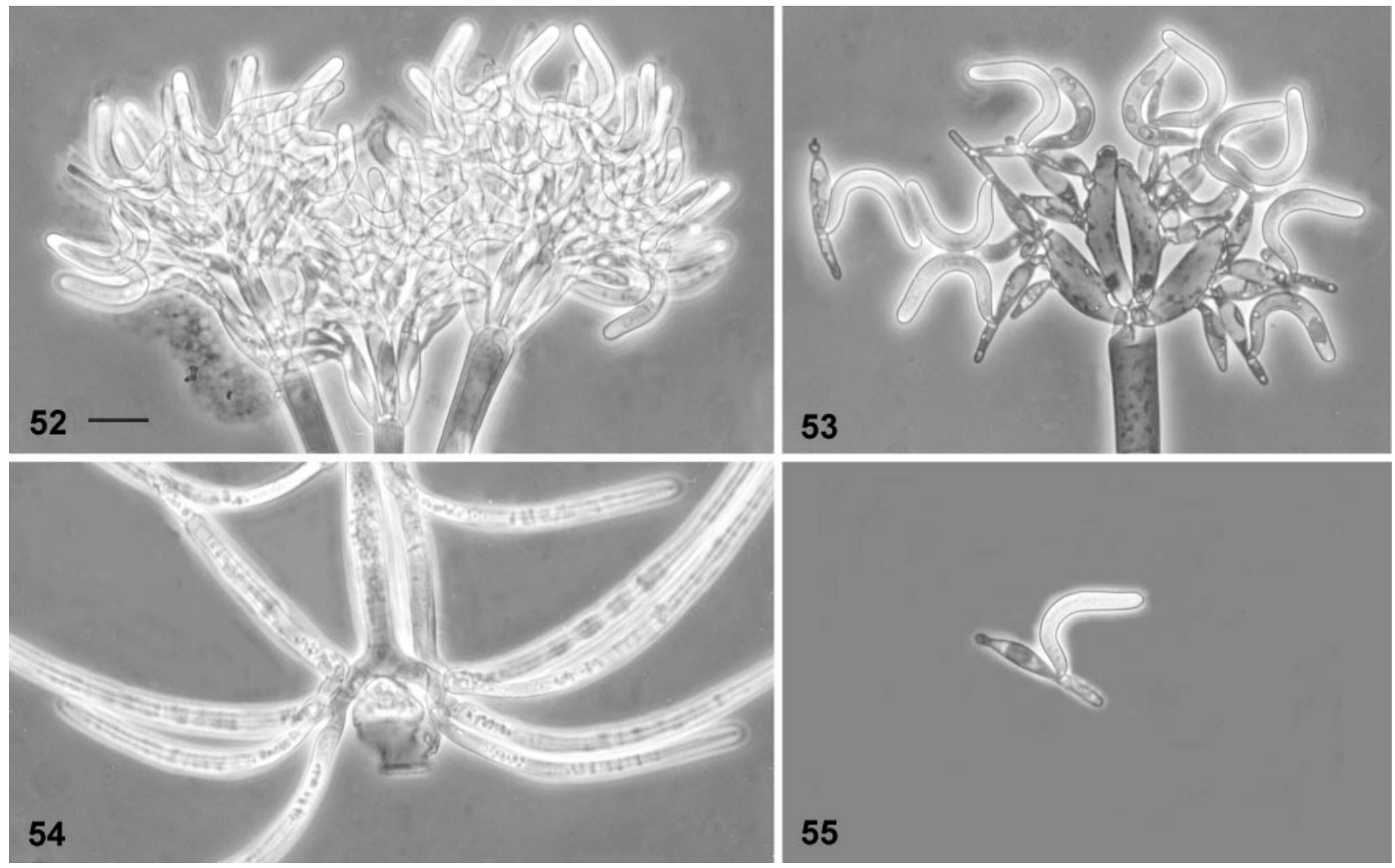

Figs. 52-55. Orphella coronata from nymphs of Nemoura cinerea (Plecoptera: Nemouridae). 52. Sporulating head of a thallus with allantoid trichospores (\# NOR-33-W8). 53. Dissemination units releasing from a sporulating head (\# NOR-19W7). 54. Base of a thallus with a bulbous holdfast cell (\# NOR-19-W3A). 55. A dissemination unit consisting of an allantoid trichospore and two auxiliary cells (\# NOR-5-W10). Scale bar $=20 \mu \mathrm{m}$.

\section{Pennella arctica Lichtw. \& M.C. Williams}

Pennella arctica has been reported from northern Sweden and northwestern Montana in several different species of Simuliidae (Lichtwardt 1984). We found this fungus to be common in Norway with records for various species of Simuliidae at sites 2, 7, 22, 26, 28, 33 and 42 (see Harpella melusinae above for a list of some of these simuliids). In some instances we pooled (immature) nonsporulating and (mature) sporulating stages of this species of Pennella spp. within sites because this is a genus that can be identified by the characteristic simple to dichotomously branched basal cell that attaches to the cuticle by a mucilaginous substance (e.g., see FIGs. 29 and 30 in Lichtwardt et al 2001b).

\section{Simuliomyces microsporus Lichtwardt}

This species has been found in Simuliidae larvae in Australia, France, Great Britain, Sweden, U.S.A. (Lichtwardt et al 2001a) and now Norway. In most instances this interesting species does not attach directly to the hindgut cuticle but rather to thalli of other gut inhabitants. In Norway we found it attached to Pennella arctica or Paramoebidium spp.
(Amoebidiales) but it is also known to attach to Genistellospora homothallica Lichtwardt. (Species of Amoebidiales are protists that were once considered to be Trichomycetes and may be found in Simuliidae larvae but even more commonly in nymphs of mayflies and stoneflies. We found Paramoebidium spp. frequently in Norway [sites 2, 3, 4, 5, 6, 7, 8, 10, 11, 12, $15,16,19,20,21,22,30,33,35,40,42,43,50,52$, $53,54,61]$ but these are not reported in detail in this paper.) Simuliomyces microsporus was collected at sites 2, 7, 11, 30 and 33.

\section{Smittium coloradense Lichtw. \& M.C. Williams}

Our specimens of Sm. coloradense were obtained from a chironomid midge collected from a seeping cliff in Norway (Site 46). It appears to be the same species originally described in various genera of Chironomidae and Prosimulium (Simuliidae) larvae taken from a stream in the Rocky Mountains of Colorado (Williams and Lichtwardt 1987b, Lichtwardt and Williams 1988), based on trichospore morphology and the characteristic tapered basal cell with protrusions. Beard and Adler (2003) subsequently reported Sm. coloradense from chironomid larvae cling- 


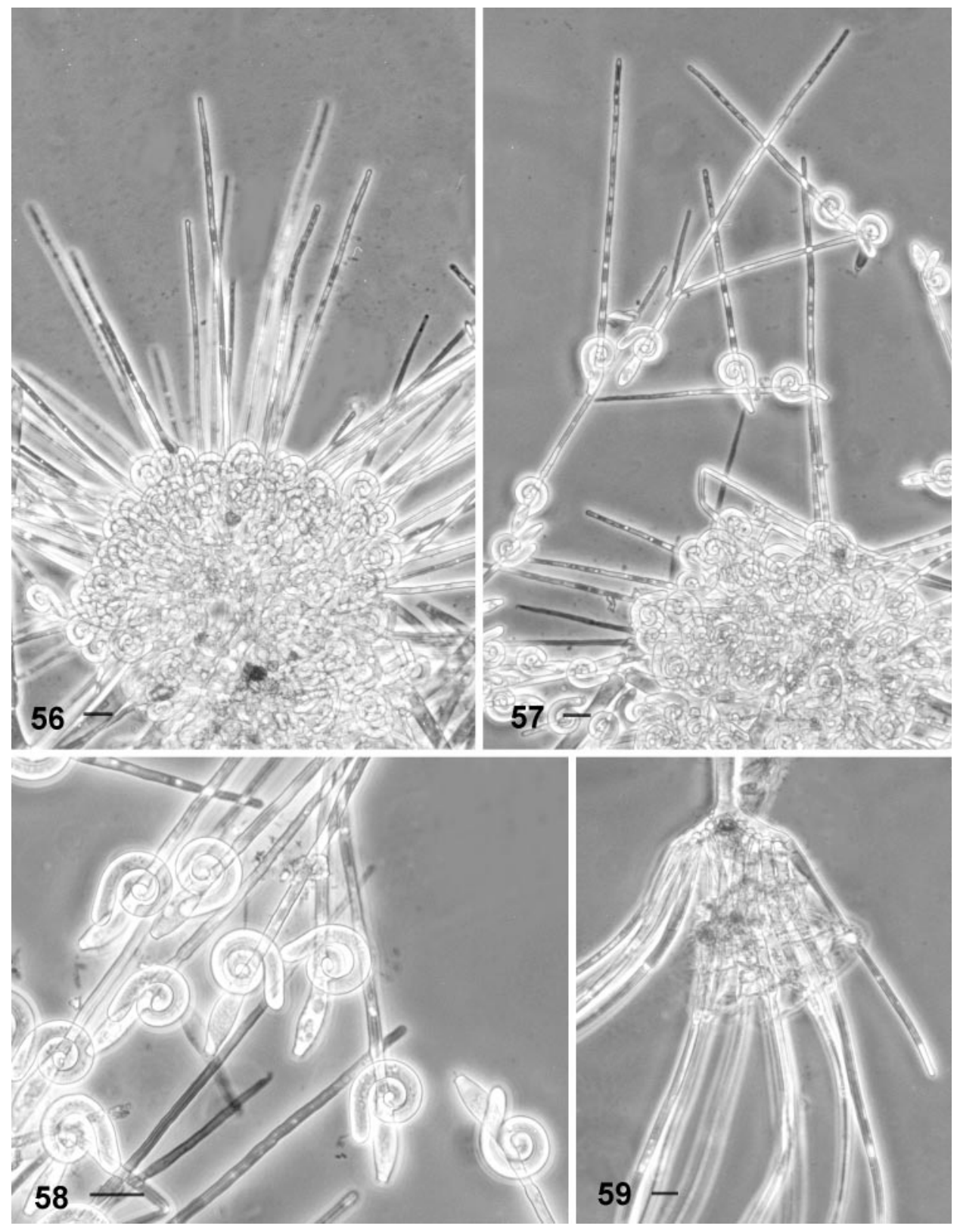

Figs. 56-59. Orphella helicospora in nymphs of Nemoura cinerea (Plecoptera: Nemouridae). 56. A dense sporulating head (\# NOR-10-W3). 57, 58. Sporulating heads releasing dissemination units with long, terminal filamentous cells; in other specimens the terminal cells may be much shorter (\# NOR-10-W3). 59. Bifurcate branching at the base of a thallus (\# NOR11-W17). Scale bars $=20 \mu \mathrm{m}$.

ing to a seeping cliff in South Carolina and described zygospores for the first time. A few of the many trichospores in the Norwegian collection were slightly longer $(25-40 \times 7-8 \mu \mathrm{m})$ than originally described for the species $([17-] 26[-32] \times[7-] 8[-9.5] \mu \mathrm{m})$, but collar lengths were similar $(3-3.5 \mu \mathrm{m})$. Zygospores of this fungus were not found in Norway.

\section{Smittium culicis Manier}

We found $\mathrm{Sm}$. culicis, essentially a worldwide spe- cies with a wide host range among families of nematoceran Diptera, in mosquito larvae at Site 45A, in chironomid larvae of Orthocladius (Eudactycladius) fuscimanus (Kieffer) (Site 17), Diamesa aberrata Lundbeck (Site 18), and Psectrocladius (Psectrocladius) limbellatus group (Sites 38, 59). Smittium culicis also was present in larvae from Site 17, living in the same guts with the new species Smittium precipitiorum described above. The following axenic cultures of Sm. culicis (listed with the hosts from which they were 
extracted) were isolated and have been deposited in University of Kansas Mycological Culture Collection (KUMYCOL): NOR-25-W3, NOR-25-W10A, NOR-45W17, NOR-45-W22 (all from mosquitoes) and NOR59-2 (from Psectrocladius limbellatus group).

\section{Smittium mucronatum Manier \& Mathiez ex Manier}

The discovery of Sm. mucronatum in larvae of Psectrocladius (Psectrocladius) limbellatus group from two collections at a small rock pool (sites 58 and 62) in Norway presents an interesting biogeographical distribution. Originally described from southern France in larvae of $P$. sordidellus (Zett.) (Manier and Mathiez 1965), it later was discovered in a high altitude kettle pond in Colorado, within an undetermined species of Psectrocladius (Lichtwardt and Williams 1999). Thus, all three disjunct records of Sm. mucronatum are in the same chironomid genus. The trichospore has a minute nipple at its tip, and the fungus produces Type II zygospores, characters that confirm the identity of the fungus in all three geographic regions. The trichospores and zygospores from Norway were at the lower range of those published for this species, but the trichospore nipple and host association substantiate the species identification. Axenic cultures of Sm. mucronatum were obtained from France (Lichtwardt 1986) and Colorado (Lichtwardt and Williams 1999) but not from Norway. These isolates have been used for several physiological, host specificity and molecular systematic studies (Lichtwardt et al 2001a, Gottlieb and Lichtwardt 2001, White 2002).

\section{Smittium simulii Lichtwardt}

Smittium simulii, like Sm culicis, has been found on many continents and in many families of nematoceran Diptera (Lichtwardt et al 2001a). In Norway we found this fungus not only in simuliid larvae at sites 8 and 28, but also in mosquito larvae (Culicidae) at sites 25 and 32 . This is apparently only the second finding of $\mathrm{Sm}$. simulii in mosquitoes (also recently observed in Spain by Valle and Santamaria pers comm). An axenic isolate, NOR-28-7, was obtained and accessioned in the KUMYCOL.

\section{Stachylina pedifer M.C. Williams \& Lichtw.}

At Site 21 we found in the peritrophic membrane of an unidentified chironomid larva thalli and trichospores that appear to be morphologically similar to St. pedifer found in northwestern Montana, on larvae of Boreoheptagyia lurida (Garrett). Thalli of St. pedifer are small with a foot-like swelling at the base that penetrates the peritrophic membrane, and produce 2-8 trichospores per thallus (Lichtwardt and
Williams 1983). Stachylina pedifer also has been found in South Carolina by Beard and Adler (2003), who induced previously unknown zygospores in vitro.

\section{DISCUSSION}

Trichomycetes were common in Norway, and many were found that added new species or extended the hosts and ranges of previously known species, with no major departures from expected morphologies. However, Ephemerellomyces aquilonius had a novel stage of trichospore development. The source of the trichospores that attach to and germinate on the hindgut cuticle of this new genus and species is not known (Figs. 4-6). They might be trichospores that had been ingested by the larvae or ones that were produced by established thalli within the gut. The uniqueness of their development is that the germination process yields a cell that functions as a generative cell to produce a single trichospore. Replication of thalli within the gut by internally produced spores is common in Eccrinales but rare in Harpellales. In the latter order, examples are Graminella spp. from Baetidae (Ephemeroptera), where specialized detachable branches break off from thalli, attach to the cuticle and grow into sporulating thalli (see illustrations in Lichtwardt and Moss 1981 or Lichtwardt and Arenas 1996); and in the monotypic Western Australian genus Allantomyces from Caenidae (Ephemeroptera), specialized allantoid cells are produced on branchlets, detach and produce new thalli in the same gut (Williams and Lichtwardt 1993). But in none of the species of these two genera do the vegetative propagules resemble the apparent trichospore attachment and germination in E. aquilonius.

Generic placement of Genistelloides communis from Nemouridae nymphs is based primarily on the nature of the two relatively heavy appendages arranged in a helix when they first emerge from their generative cells. (Figs. 12, 13). This is similar to G. helicoides originally described from Nemouridae nymphs in the Rocky Mountains of Colorado (Williams and Lichtwardt 1987a) but now also known from other streams in eastern North America (unpublished). In neither species are zygospores known, but zygospores (Type I [Moss et al 1975], similar to FIG. 9 in this paper) were described in the type species, G. hibernus (Peterson et al 1981), which lives in Allocapnia spp. nymphs (Plecoptera: Capniidae) throughout much of eastern U.S.A. (Lichtwardt et al 1993). Zygospores (Type I) are necessary to confirm the generic placement of these two species from nemourids. It is possible that G. communis is more closely related to Lancisporomyces vernalis Santamaria (Santamaria 1997), a monotypic genus described from Nemoura sp. in 
Spain. Lancisporomyces has unique lance-shaped zygospores (Type IV), discovery of zygospores in $G$. communis consequently would provide confirmation of the correct genus.

The discovery of some previously known, widespread, harpellid species in Norway is not surprising. Harpella melusinae, Simuliomyces microsporus, Smittium culicis and Sm. simulii (although the latter's occurrence in mosquitoes is unusual) all have wide geographical distributions in their respective types of hosts. A less common harpellid, however, demonstrates a disjunct distribution: Smittium mucronatum first was discovered in France (Manier and Mathiez 1965), later in Colorado (Lichtwardt and Williams 1999) and now in Norway. In all three instances the respective fungi were found in different species of the same chironomid genus, Psectrocladius. As another example, Harpellomyces eccentricus now is known from Norway (this study), Sweden, Wales (Lichtwardt and Moss 1984) and Spain (Santamaria and Girbal, 1997); Harpellomyces abruptus was described from Newfoundland (Lichtwardt et al 2001b) (with possibly another, unpublished species in the U.S.A.); and a species of Harpellomyces was recorded from Japan (Lichtwardt et al 1987, but probably not H. eccentricus as indicated in that publication). Harpellomyces in Europe, North America and Japan all were living in different species of Thaumalea. Only T. verralli Edwards in Canada was identified to species because of difficulty in identifying larval stages of thaumaleids. In Australia, Austrothaumalea spp. hindguts did not contain Harpellomyces but were infested with Smittium culicis (a species adapted to many nematoceran families) from which five axenic isolates were obtained (Lichtwardt and Williams 1990).

The three Orphella spp. we found in Norway are known only from Europe. Orphella spp. in the U.S.A. are different from those in Europe, with the exception of Orphella haysii, originally described from Colorado (Williams and Lichtwardt 1987a) in nymphs of Zapada haysi Ricker, Z. cintipes Banks, and Malenka flexura Claassen (Nemouridae), which Santamaria and Girbal (1998) subsequently reported from Spain in Nemoura sp. Both $O$. haysii and the European $O$. coronata are similar morphologically. It is possible that specimens of $O$. haysii found in Spain and $O$. coronata are conspecific. We expect through DNA sequencing to corroborate their identities and to test the hypothesis that Orphella spp., Harpellomyces spp. and perhaps disjunct species of other genera such as Genistelloides and Lancisporomyces have undergone vicariant speciation subsequent to severance of the last land bridges between Europe and North America as they became separated tectonically.

Our survey of Harpellales in Norway emphasizes the need for continued efforts to find and identify these endosymbionts, not only in unexplored regions of the country (not covered in this survey) but also beyond it to estimate more accurately their biodiversity with a global perspective.

\section{ACKNOWLEDGMENTS}

We are indebted to the National Science Foundation for award DEB-0108110, which supported this research. We acknowledge with considerable appreciation a number of biologists in Norway whose assistance materially facilitated our research and made it more successful. Leif Ryvarden provided excellent laboratory space and facilities in the Department of Botany, University of Oslo. John E. Brittain, Trude Vrålstad and Arne Holst-Jensen suggested a number of collecting sites in the vicinity of Oslo. Arne Fjellheim, Stavanger Museum, allowed use of the subalpine Field Station at Ekse administered by the University of Bergen, and arranged, through Ole Kristian Berg, Zoologisk Institutt, University of Trondheim, our use of the Snåsavatnet Field Station in the northern part of Trondheimsfjord. We thank these entomologists for their considerable time and expertise in identifying larval hosts of Harpellales: John E. Brittain (Plecoptera and Ephemeroptera) and Jan Emil Raastad (Simuliidae), The Natural History Museums, University of Oslo; Ole A. Sæther (Chironomidae), Museum of Zoology, University of Bergen; and Brad Sinclair (Thaumaleidae), Museum Koenig. We thank Matías Cafaro who provided valuable comments on a draft of this manuscript. We also are grateful for the thoughtful comments of C. Eddie Beard and an anonymous reviewer that improved the paper.

\section{LITERATURE CITED}

Beard CE, Adler PH. 2003. Zygospores of selected Trichomycetes in larval Diptera of the families Chironomidae and Simuliidae. Mycologia 95:317-320.

Gottlieb AM, Lichtwardt RW. 2001. Molecular studies of selected Harpellales (Trichomycetes). Mycologia 93:6580.

Hynes HBN. 1976. Biology of Plecoptera. In: Smith RF, Mittler TE, Smith CN, eds. Ann Rev Entomol. Palo Alto: Annual Reviews. p 31-37.

- 1988. Biogeography and origins of the North American stoneflies (Plecoptera). Mem Entomol Soc Can 144:31-37.

Léger L, Gauthier M. 1931. Orphella coronata n.g. n.sp. entophyte parasite des larves de Nemurides. Trav Lab Hydrobiol Pisciculture 23:67-72.

_ - 1932. Endomycètes nouveaux des larves aquatiques d'Insectes. C R Acad Sci Paris 194:22622265.

Lichtwardt RW. 1984. Species of Harpellales living within the guts of aquatic Diptera larvae. Mycotaxon 19:529550 .

- 1986. The Trichomycetes, fungal associates of arthropods. New York: Springer-Verlag. 343 p. 
, Arenas J. 1996. Trichomycetes in aquatic insects from southern Chile. Mycologia 88:844-857.

, Cafaro MJ, White MM. 2001a. The Trichomycetes, fungal associates of arthropods. Revised ed. published on the Internet: www.nhm.ku.edu/\% 7Efungi/ Monograph/Text/Mono.htm.

-, Huss MJ, Williams MC. 1993, Biogeographic studies on trichomycete gut fungi in winter stonefly nymphs of the genus Allocapnia. Mycologia 85:535-546.

— Kobayasi Y, Indoh H. 1987. Trichomycetes of Japan. Trans Mycol Soc Japan 28:359-412.

- Moss ST. 1981. Vegetative propagation in a new species of Harpellales, Graminella microspora. Trans Br Mycol Soc 76:311-316.

- -1984 . Harpellomyces eccentricus, an unusual Harpellales from Sweden and Wales. Mycotaxon 20: 511-517.

- White MM, Colbo MH. 2001b. Harpellales in Newfoundland aquatic insect larvae. Mycologia 93:764-773.

—, Williams MC. 1983. Two unusual Trichomycetes in an aquatic midge larva. Mycologia 75:728-734.

- 1988 . Distribution and species diversity of trichomycete gut fungi in aquatic insect larvae in two Rocky Mountain streams. Can J Bot 66:1259-1263.

- 1990 . Trichomycete gut fungi in Australian aquatic insect larvae. Mycologia 68:1057-1074.

— -1999 . Three Harpellales that live in one species of aquatic chironomid larva. Mycologia 91:396399.

Manier J-F, Mathiez F. 1965. Deux Trichomycètes Harpellales Genistellacées parasites de larves de Chironomides. Ann Sci Nat Bot Veg Paris Ser 12 6:183-196.

Moss ST, Lichtwardt RW, Manier J-F. 1975. Zygopolaris, a new genus of Trichomycetes producing zygospores with polar attachment. Mycologia 67:120-127.

Peterson SW, Lichtwardt RW, Horn BW. 1981. Genistelloides hibernus: a new trichomycete from a winter-emerging stonefly. Mycologia 73:447-485.

Santamaria S. 1997. Lancisporomyces, a new genus of Trichomycetes with lance-shaped zygospores. Mycologia 89:639-642.

Santamaria S, Girbal J. 1997. Contributión al conocimiento de los Trichomycetes (Fungi, Zygomycotina) Ibéricos. Anales del Jardín Botánico de Madrid 55:219-223.

— Girbal J. 1998. Two new species of Orphella from Spain. Mycol Res 102:174-178.

Stewart KW, Stark BP. 1988. Nymphs of North American stonefly genera (Plecoptera). Lawrence, Kansas, USA: Allen Press Inc. p 460.

Valle LG, Santamaria S. 2002. Tectimyces, a new genus of Harpellales on mayfly nymphs (Leptophlebiidae) in Spain. Mycol Res 106:841-847.

White MM. 2002. Taxonomic and molecular systematic studies of the Harpellales (Trichomycetes) toward understanding the diversity, evolution and dispersal of gut fungi [Doctoral dissertation]. Lawrence: University of Kansas. 177 p.

Williams MC, Lichtwardt RW. 1987a. Two new trichomycete species from Zapada spp. (stonefly) nymphs with an unusual distribution. Mycologia 79:473-478.

. 1987b. Three new species of Smittium (Trichomycetes) with note on range extensions. Mycologia 79:832-838.

, - 1990. Trichomycete gut fungi in New Zealand aquatic insect larvae. Can J Bot 68:1045-1056.

-1 . 1993. A new monotypic fungal genus, $A l$ lantomyces, and a new species of Legeriomyces (Trichomycetes, Harpellales) in the hindgut of a Western Australian mayfly nymph (Tasmanocoenis sp.). Can J Bot 71:1109-1113.

- 1 1999. Two new Harpellales living in Ephemeroptera nymphs in Colorado Rocky Mountain streams. Mycologia 91:400-404. 